\title{
REVISIONAL STUDY OF \\ THE ORDER PALAEODICTYOPTERA IN THE UPPER CARBONIFEROUS SHALES OF COMMENTRY, FRANCE. PART $\mathrm{I}^{1}$
}

\author{
By Jarmila Kukalova ${ }^{2}$ \\ Charles University, Prague
}

The Upper Carboniferous shales in Commentry, France, are of incomparable significance for the study of insect evolution. The excellent preservation of the fossils and the diversity of insect groups represented make the Commentry fossils basic to any understanding of Palaeozoic insects and early insect evolution.

Almost all of the Commentry insects are contained in the Institut de Paléontologie in the Muséum National d'Histoire Naturelle, Paris, this constituting the largest assemblage in the world of Upper Carboniferous insects. A very few Commentry specimens are in the British Museum (Natural History) in London and in the Manchester Museum (Stirrup Collection), Manchester, England.

The Commentry shales are part of a small coal basin, situated on the north side of the large Carboniferous furrow of the Massif Central. The fossiliferous layers are of fresh water origin and are allochthonous, apparently deposited by streams in delta-like, detritic sediments along the shore of a lake. During his early study on stratigraphy and sediments (I880-1890), based on surface outcrops of the Commentry beds, Fayol assembled the greater part of the collection of fossil insects. This remarkable collection was turned over to Charles Brongniart (grandson of the palaeobotanist, Adolphe Brongniart), who was then an assistant in the Zoological Laboratory of the Muséum and who was interested in both geology and entomology. Brongniart's studies were brought out in a single major work, "Recherches pour servir à l'histoire des insectes fossiles des temps primaires", published in I893. This was a pioneer work in the study of fossil insects. Although his classification of the insects is now seriously out-dated, Brongniart demonstrated in his illustrations and his descriptive accounts an exceptional ability for observa-

\footnotetext{
${ }^{1}$ Published with the aid of a grant from the Colles Fund of the Museum of Comparative Zoology at Harvard College and a Grant-in-Aid of Research from the Society of the Sigma Xi. This study has also been supported in part by grants numbered GB2038 and GB7038 (F. M. Carpenter, Principal Investigator) from the National Science Foundation.

${ }^{2}$ Currently Alexander Agassiz Lecturer in Zoology, Harvard University.
} 
tion. The collection at the Muséum has not been subjected to extensive restudy until recent years. Even Handlirsch, in connection with his monograph of fossil insects in 1906-1908 and his revision of Palaeozoic insects in 1919, made no examination of the Commentry fossils in the Muséum. Many additional Commentry insects were found and placed in the Muséum subsequent to Brongniart's death in I899. Most of these were studied and described by Fernand Meunier in a series of superficial and confusing papers (1907-192I). Professor Aug. Lameere of Belgium, however, did make a careful study of both the original Brongniart material and the specimens later accumulated; his most significant account (1917) dealt with corrections in morphological details and systematics given by Brongniart and Meunier; his observations were remarkably good, although the complete absence of illustrations make the use of his revision somewhat difficult.

In 1935 Professor F. M. Carpenter, realizing both the significance of the Commentry insects and the lack of reliable information about them, decided to make a systematic study of the collection in the Paris Museum in connection with his investigations on Permian insects. He visited the Muséum first in 1938, making photographs of all the type specimens, as well as drawings of specimens of some families. Following three other visits to the Muséum (1961, 1962 and 1966), he published accounts revising the Commentry Protodonata, Megasecoptera, Diaphanopterodea, Ephemeroptera, and Caloneurodea. In 1967, realizing the extent of the fossils in the Commentry collection still remaining to be studied, he encouraged me to work on the large order Palaeodictyoptera, a group having more representation in the Commentry collection than in all other collections in the world combined. He turned over to me all the photographs and notes which he had previously made, and he obtained financial support from the Scientific Research Society (Sigma $\mathrm{Xi}$ ) and the National Science Foundation for my visits to the Museum in Paris (1966, 1967) and my work in his laboratory at Harvard University. I am deeply indebted to Professor Carpenter for his assistance, without which the preparation and publication of these studies would not have been possible.

During my stay at the Institut in Paris, I was enabled, through the courtesy of the Director, Professor J. P. Lehman, to restudy all specimens of Palaeodictyoptera in the Muséum collection. Dr. J. Sornay of the Institut also kindly gave me great assistance with the collection. Unfortunately, some of the specimens previously present could not be found in 1966 or 1967 , the only record of them 
being the photographs made by Professor Carpenter during his stay in Paris before the beginning of World War II. Although photographic documentation, especially of fossil insects, can be very misleading, I decided finally to include figures based on the photographs of these missing specimens, since they provide at least some basis for evaluating the original figures and descriptions given by Brongniart or Meunier. It is still my hope that the missing types will turn up so that more definitive figures can be made later.

For practical reasons, this revisional study will be published in three parts, as follows:

Part I. Spilapteridae (including Lamproptiliidae), Fouqueidae, Mecynostomatidae, fam. nov.

Part 2. Homoiopteridae, Lycocercidae (including Apopappidae), Graphiptilidae (including Rhabdoptilidae), Breyeriidae, Eugereonidae (including Peromapteridae, Dictyoptilidae), Archaemegaptilidae, Megaptilidae (including Lithoptilidae).

Part 3. Dictyoneuridae (including Stenodictyidae).

The first two parts will be entirely systematic, but the third will include, in addition to the systematic account of the Dictyoneuridae, a discussion of the morphological features of the Palaeodictyoptera.

Since the Commentry insects in the Paris Institut have not been given catalogue numbers, I have followed Professor Carpenter's procedure of referring to Brongniart's specimens by plate and figure numbers as they appeared in his monograph (1893, thesis edition); thus, I7-7, refers to the fossil shown in his figure 7 , of plate 17 .

Family Spilapteridae Brongniart

nom. correct. Handlirsch, 1906: 101, pro Spilapterida

Brongniart, 1893: 334 .

Spilapteridae, Handlirsch, 1906: 101; Lameere, 1917: 102; Handlirsch, 1919: 20.

Lamproptiliidae, Handlirsch, 1960: 109; Lameere, 1917: 102; Handlirsch, 1919: 21. New synonymy.

Dunbariidae, Handlirsch, 1937: 81.

Doropteridae, G. Zalessky, 1947: 64 .

Neuburgiidae, Rohdendorf, 1961: 72.

Type Genus: Spilaptera Brongniart, 1893.

This family, the largest in the order Palaeodictyoptera, was established by Brongniart as a subfamily and subsequently raised to family level by Handlirsch in 1906. Within the order, this family not only has the most extensive fossil record but also the longest range 
(Namurian $\mathrm{C}$ to Lower Permian) and wide geographical distribution (North America, Europe and Asia).

Unlike many other Palaeodictyoptera with a tendency to reduce the hind wings, the Spilapteridae and related families always have well-developed hind wings, which are markedly broadened in the basal half. 'The wing venation is very uniform throughout the family and seems to have been continued into the Lower Permian with relatively little change. The detailed branching of the veins, however, is highly variable, even within a single individual. As a result, any classification based upon details of branching of the veins is very questionable.

This study of the Commentry Palaeodictyoptera has brought to light a great deal about the structure of the wings and the body. In the wings transverse structures apparently concerned with strengthening the membrane have turned out to be very characteristic of some genera; since they were diverse, being either cuticular thickenings, oblique cross veins, or oblique, pigmented stripes, they are useful in classification. Many details of body structures not previously noted were observed; these included the fine structures of the antennae, the clypeus, and the prothoracic lobes. To some extent, their variability within the Palaeodictyoptera is now known. As a result of this more precise and extended knowledge of the structure of the Spilapteridae, I have found it necessary to make some taxonomic changes. Lamproptilia Brongniart, which is known from fore and hind wings, has a typical spilapterid venation, differing from other genera of the family only in the relatively broad fore wings, the convex curvature of the posterior margin of the hind wing, and the color pattern. None of these features seem to justify more than generic separation. Several generic changes also seem necessary: Compsoneura Brongniart, originally referred to the Spilapteridae, is herein placed with some doubt in the family Fouqueidae. Apopappus guernei (Brongniart), also originally placed in the Spilapteridae, is now put in the Lycocercidae. The new genus Tectoptilus is based on Becquerellia grehanti Brongniart. The new species, Homaloneura lehmani, is based upon one of Brongniart's specimens (I7-I5), which he erroneously thought was the reverse of his type of Homaloneura ornata.

The following are the characteristics which now seem to be valid for the Spilapteridae: wings about equal in length and similar in venation, but the hind wings broader basally; supporting structures often present in basal third of the wings; precostal strip present; anterior margin of wings more or less concave. Sc long, $\mathrm{R}$ simple or 
with terminal branches; Rs with 3-10 pectinate branches; both MA and MP with at least two branches, usually more; $\mathrm{CuA}$ with several branches, $\mathrm{CuP}$ with few branches or even simple; several anal veins. Cross veins mostly simple and not very numerous. The wings are often marked with broad transverse bands or with spots. Body structures: Head small, broad, with large projecting eyes and a large striated clypeus. Beak long; antennae long, with many long segments. Prothoracic lobes with radiating veins and with cross veins, but sometimes heavily sclerotized with the venation reduced or very weak. Metathorax usually somewhat longer than the mesothorax. Legs short, cursorial. Abdomen relatively slender, the females with ten visible segments and a short ovipositor; cerci in both sexes long and robust. Males of at least some genera with terminal claspers. Posterior-lateral angles of the abdominal tergites small and not projecting.

The family Spilapteridae differs from all other families in the order, excepting the Homoiopteridae (including Rochlingiidae and Thesoneuridae), Mecynostomatidae, Fouqueidae, and Eubleptidae, in having MA and $\mathrm{CuA}$ branched. Of these four families, the Homoiopteridae show no close relationship to the spilapterids; Mecynostomatidae, on the contrary, might have been derived from spilapterid ancestors. The Fouqueidae are very close to the Spilapteridae on the basis of their venation, which differs only in the tendency to have fewer branches on MA and more branches on $\mathrm{CuP}$; they have been recognized as a distinct family mainly on the presence of a very dense coarse pattern of cross veins. It might turn out, as explained further below, that the Fouqueidae will be inseparable from the spilapterids. The Eubleptidae are apparently closely related to the Spilapteridae (Carpenter, 1965, p. I80); the family includes smaller species than those found in the Spilapteridae and is further characterized by having a less developed $\mathrm{CuA}$ and the presence of an archedictyon combined with cross veins.

The following Commentry genera are herein included in the family Spilapteridae: Spilaptera Brongniart, Homaloneura Brongniart, Becquerelia Brongniart, Palaeoptilus Brongniart, Epitethe Handlirsch, Tectoptilus gen. nov., Spiloptilus Handlirsch, and Lamproptilia Brongniart. Genera which appear to belong in the family, although not occurring in the Commentry shales, are the following: Severinopsis Kukalova, 1958 (Namurian C, Czechoslovakia); $M c$ luckiepteron Richardson, 1956 (Westphalian, Illinois); Neuburgia Martynov, I93 I (Stephanian, Kuznetsk); Dunbaria Tillyard, I924 (Lower Permian, Kansas); Oboria Kukalova, 1958 (Lower Per- 

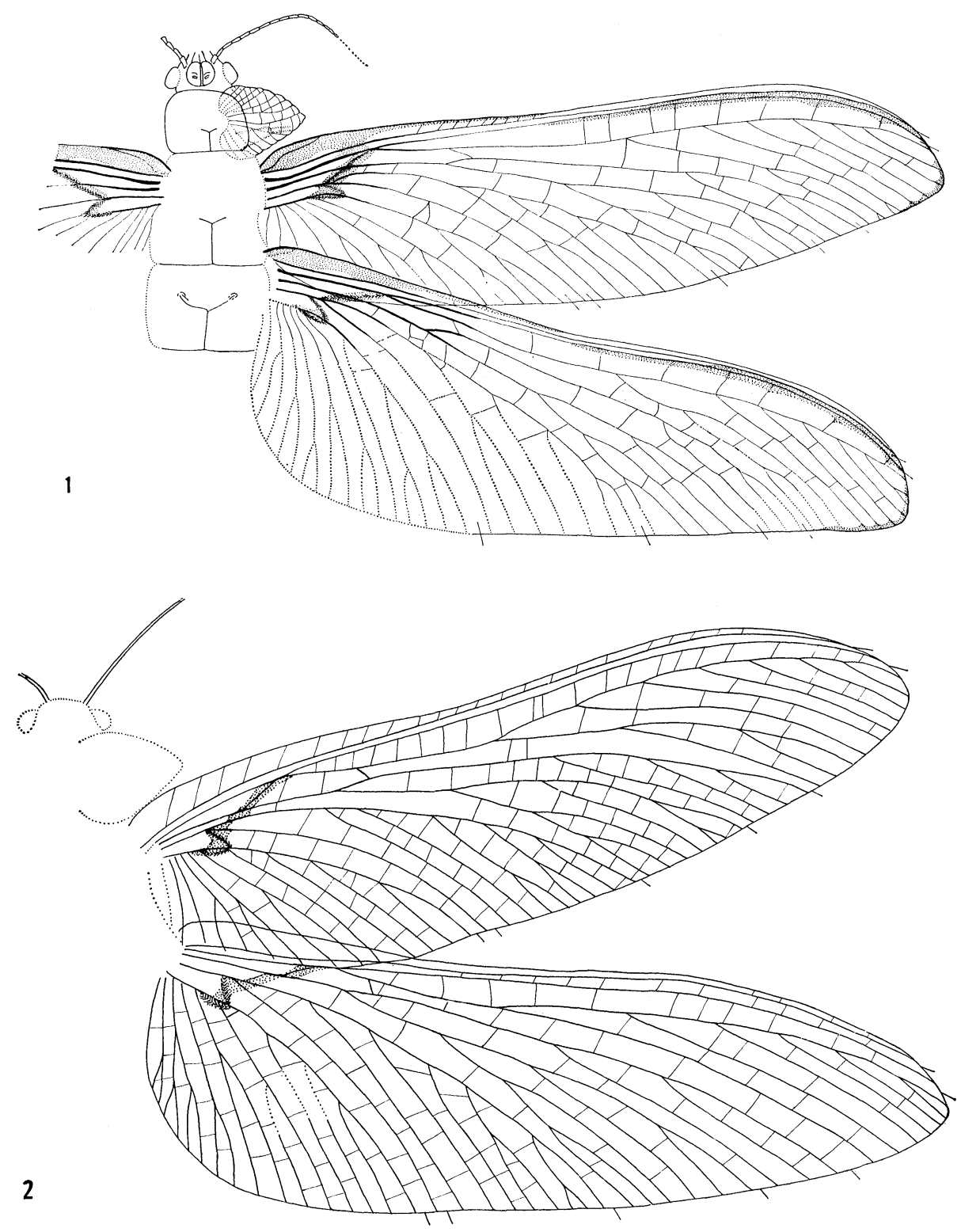

Figure 1. Homaloneura elegans Brongniart; specimen 17-11. Holotype. Figure 2. Homaloneura elegans Brongniart; specimen 17-12. 
mian, Czechoslovakia) ; Doropteron G. Zalessky, 1946 (Lower Permian, Ural, USSR) ; Permiakovia Martynov, I940 (Lower Permian, Ural, USSR) ; Abaptilon G. Zalessky, I946 (Stephanian, Kuznetsk). The genus Homaloneura occurs in the Westphalian of Illinois as well as in the Commentry shales (Carpenter, I964, p. I I $7 \mathrm{ff}$ ).

\section{Genus Homaloneura Brongniart}

Homaloneura Brongniart, 1885: 66; Brongniart, 1893: 316; Handlirsch, 1906: 107; Lameere, 1917: 148; Carpenter, 1964: 119.

Homaloneurina Handlirsch, 1906: Lameere, 1917: 148; Handlirsch, 1919: 20.

Homaloneurites Handlirsch, 1906: 107; Lameere, 1917: 147; Handlirsch, 1919: 20.

Type species: Homaloneura elegans Brongniart, I885(OD).

Although Brongniart originally erected Homaloneura for a single species (elegans), he added five more species in 1893: bonnieri, punctata, joannae, ornata, and bucklandi. In 1906, Handlirsch formed two new genera, their type species being two of those described by Brongniart: he established Homaloneurina for bonnieri and Homaloneurites for joannae. Both of these genera were rejected as unnecessary by Lameere (I9I7), a view which is undoubtedly correct and which is followed here. An additional species, lehmani, is described below; this is based upon Brongniart's specimen I7-I5, which Brongniart erroneously considered to be the reverse half of the type specimen of ornata.

The basic venational pattern within Homaloneura is uniform, and many morphological features seem to have appeared independently among the species. It is usual for the species of Homaloneura to have cuticular thickenings, supporting cross veins, and color bands in the basal third of both pairs of wings. These structures presumably strengthen transversely the thin wing membrane. Among palaeopterous insects, they are most pronounced in the Odonata, but they occur in other orders as well. In the Palaeodictyoptera, they are most spectacularly represented by the Calvertiellidae (Kukalova, 1964). The strengthening structures in the wings of Homaloneura were noted originally by Brongniart ( 1893 , p. 318), but neither Handlirsch nor Lameere made mention of them. In Homaloneura elegans, bonnieri, parva, and dabasinskasi, the cuticular thickening is a conspicuous $\mathrm{V}$-shaped ridge with its apex on AI. In ornata, joannae, and lehmani, the cuticular ridge is directly on $\mathrm{AI}$, strengthening it for a short distance where it abruptly bends toward the posterior margin. Present in all species is a long, oblique, strong cross vein, running 
from $M$ to $R$, usually at the point of origin of Rs. In elegans and bonnieri, there is additional strengthening by means of a dark colored band running obliquely from $A_{I}$ to $R$.

The body structures of Homaloneura were figured very roughly by Brongniart, and, with the exception of the prothoracic lobes and legs, they were not mentioned by Lameere. Actually, most of these structures are visible only under glycerin or glycerin-alcohol, but with the use of this clearing solution, the specimens of Homaloneura have contributed a great deal to our knowledge of the morphology of the Palaeodictyoptera. Most important is the presence of a large, bulging clypeus, with transverse ridges, best preserved in $H$. lehmani, which I first noted when I examined this specimen under glycerin in 1966. The structure of the clypeus is surprisingly like that of some Homoptera, such as the Cicadidae, and it undoubtedly indicates that in the Palaeodictyoptera a cibarium was present, much as in the true bugs. This was presumably developed in connection with the sucking beak. In the specimen of lehmani, the sheath of the beak is bent to one side, but the stylets are close together, not separated.

Another definite morphological feature of the species of Homaloneura is the prothoracic lobes. These were presumably homologous with wings, but in any event, they show longitudinal veins as well as cross veins, and they are attached to the prothorax along a short, cuticular ridge, corresponding to the articular region of the mesoand metathoracic wings. The prothoracic lobes are cordate and more or less sclerotized, the veins showing no convexities or concavities. The lobes were somewhat higher on the thorax than the meso- and metathoracic wings, and there was apparently some space between them and the front wings in many species. The size of the lobes varies in the species of the genus. In those species in which the lobes were large, they apparently overlapped to some extent the fore wings. Since there is no indication of articular plates at the base of the lobes, active movement of the lobes in these Palaeodictyoptera is eliminated. There is a possibility, however, that these lobes might have functioned as vanes in directing the flowing or movement of air in relation to the moving of the front wings.

The abdomen in Homaloneura was relatively narrow. Brongniart was of the opinion that only nine abdominal segments existed in the genus Homaloneura ( 1893 , p. 316). This conclusion was apparently based on a specimen of ornata, the only Commentry specimen with the abdomen completely preserved, in which segments I-3 are shorter than the following ones, and in which the posterior margin of the 
second segment is very indistinct. There are actually ten segments visible in this specimen.

In $H$. ornata, as well as in many other Palaeodictyoptera, the lateral parts of each tergite are separated by a longitudinal line from the main portion of the sclerite. The structural significance of this is not clear. Carpenter (1969, p. 306) suggests that they might be the actual ventral margins of the tergites, their impressions resulting from the flattening of the abdomen during preservation. On the other hand, they might be homologous with the so-called "lateral lamellae" of some maylly nymphs, the function of which is apparently uncertain.

\section{Description of Genus}

Wings equal in length, or the hind pair a little longer. Wing membrane with variable color markings (transverse bands spots, longitudinal stripes). Hind wing always broader in the proximal half, but similar in venation to the fore wing. Cuticular thickenings and $\mathrm{r}-\mathrm{m}$ cross vein present. $\mathrm{R}$ without terminal branches, Rs pectinate; MA and MP forked several times; $\mathrm{CuA}$ with several branches, $\mathrm{CuP}$ simple or weakly forked. Cross veins not very numerous.

Head about as broad as the prothorax; eyes large, projecting; clypeus large, oval, with median ridges and transverse striations; beak long; antennae long, thin, with long segments. Prothorax narrower than and about half as long as the mesothorax; prothoracic lobes cordate, with about ten veins, sometimes branched, and numerous cross veins; in some species the lobes are strongly sclerotized and the venation is not visible. Meso- and metathorax almost equal in length; legs short and weak. Abdomen relatively narrow, shorter than the wings. Ovipositor short, cerci in the females robust, densely covered by hair; their structure in males is unknown.

Species of Homaloneura present in the Commentry shales: $H$. elegans Brongniart, I885; H. bonnieri Brongniart, I893; H. punctata Brongniart, I893; H. bucklandi Brongniart, I893; and $H$. lehmani sp. nov. The genus is also represented in the ironstone nodules of Illinois (Westphalian) by $H$. dabasinskasi Carpenter, I964.

\section{Homaloneura elegans Brongniart}

Figures I \& 2

Homaloneura elegans Brongniart, 1885: 66, pl. 3, fig. 2; Brongniart, 1893: 318, pl. 17, figs. 11-12, pl. 18, fig. 1; Handlirsch, 1906: 108, pl. 12, fig. 2; Lameere, 1917: 147; Handlirsch, 1919: 20.

The photograph of the type specimen was first published by Brongniart in 1885 and his figure (I7-II), in 1893 . Brongniart referred 

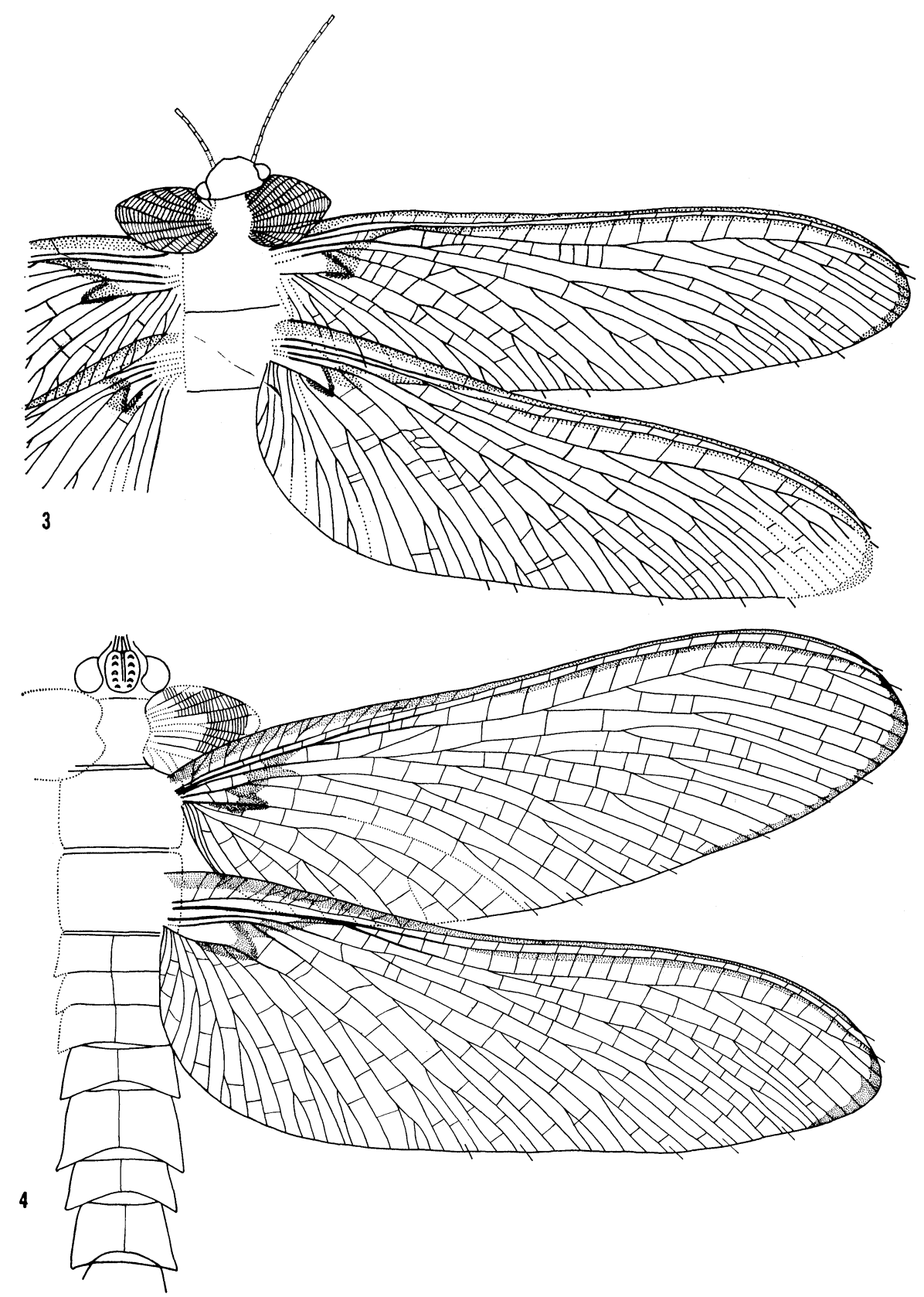

Figure 3. Homaloneura bonnieri Brongniart; specimen 17-17. Holotype. Figure 4. Homaloneura bonnieri Brongniart; specimen 17-18. 
to the same species specimen 17-12. Both obverse and reverse of I 7-I I are in the Museum, but only the badly preserved obverse of specimen I7-I 2 could be found. Fortunately, Dr. Carpenter put at my disposal a good photograph of the reverse, which he made in 1938 , so that a drawing of specimen I 7-1 2 could be worked out very satisfactorily, also. The following account is based on the type specimen.

Wings slightly unequal, the hind pair being a little longer. Wing membrane very thin. Dark stripes following costa, subcosta, apical margin, and supporting structures. Cuticular thickening V-shaped. Dark band extending from cuticular thickening obliquely to $\mathrm{R}$; $\mathrm{a}$ cross vein, rs-ma, running obliquely in the opposite direction. Fore wing: length $33 \mathrm{~mm}$, width $9.3 \mathrm{~mm}$. Anterior and posterior margins almost parallel for about two-thirds of wing length. Apical part narrowed, apex pointed, directed posteriorly. Rs with about 6-7 branches; MA pectinate, with 2-3 branches; CuP simple. Anal area with about ten branches, sometimes forked. Cross veins few, almost regular, arranged in two rows parallel with the posterior margin. Hind wing: length $34 \mathrm{~mm}$, width $\mathrm{I} 2 \mathrm{~mm}$.

Body structures: Head length $1.5 \mathrm{~mm}$, width $1.4 \mathrm{~mm}$. Eyes of average size, projecting. Clypeus almost rounded. Antennae about I $2 \mathrm{~mm}$ long, composed of equal, cylindrical segments. Prothorax half as long as mesothorax, almost square; prothoracic lobe: length $4.7 \mathrm{~mm}$, width $4 \mathrm{~mm}$, margin slightly undulated, veins about I I in number, cross veins not numerous. Mesothorax about I.4 times longer than metathorax. Fore legs very short, length of femur about $3 \mathrm{~mm}$.

In his description ( 1893 ), Brongniart mentions the V-shaped cuticular thickenings and suggests the possibility that they were stridulatory organs, which seems probably incorrect.

Homaloneura elegans is related to bonnieri by its thin wing membrane, similar color pattern and wing venation. It differs in its smaller size, shape of wings, and the much less dense cross venation of the prothoracic lobes.

\section{Homaloneura bonnieri Brongniart Figures $3 \& 4$}

Homaloneura bonnieri Brongniart, 1893: 322, 323, text fig. 12, pl. 17, figs. 17-18; Lameere, 1917; 148.

Homaloneurina bonnieri Handlirsch, 1906: 107, pl. 11, fig. 26; Handlirsch, 1921: 135, fig. 63 .

Brongniart based this species upon two specimens, I7-I7 and I7- 
I8. Since he gave a much more nearly complete figure of specimen I7-I7, I am designating it as the lectotype specimen. Handlirsch (1906) established the genus Homaloncurina for bonnieri without giving any reasons; Lameere (I9I7) was undoubtedly right in synonymizing this genus with Homaloneura, bonnieri being very close to the type species of the genus.

The type specimen I7-I7 shows four rather damaged wings, but I found that the right fore wing could be fully restored by additional preparation and the use of glycerin. Snecimen $\mathrm{I} 7-\mathrm{I} 8$, which had been badly damaged, I was able to work out much more completely after removal of all the pieces of matrix. Reconstructions of bonnieri have been attempted twice - by Brongniart ( I893, p. 323, text-fig. I2) and by Handlirsch ( I92I, p. I35, fig. 63). In both reconstructions, not one restored morphological feature is correctly shown.

Specimen I7-I 8 differs from the type specimen $17-\mathrm{I} 7$ in having much larger eyes and in the more convex apical part of the anterior margin of the fore wing, as well as in the more extensively branched MA. Nevertheless, I prefer to consider this to be bonnieri because the large eyes could be due to peculiarities of preservation or to difference in sex, and the other differences mentioned could be due to individual variability. The following account is based upon the type specimen only ( I7-I 7).

Wings equal in length, the hind pair slightly broadened basally. Wing membrane very thin; dark stripes following costa, subcosta, and supporting structures. Cuticular thickening V-shaped. Dark band extending from cuticular thickening obliquely to R. Fore wing: length $43 \mathrm{~mm}$, width $12 \mathrm{~mm}$. Anterior and posterior margins almost parallel. Apex rounded, directed slightly backwards; Rs with about six branches, MA with 2-3 branches, MP forking about five times, $\mathrm{CuA}$ with about four branches, $\mathrm{CuP}$ with one or more short branches; about eight anal veins, often forked. Cross veins few, slightly irregular. Hind wing: length $43 \mathrm{~mm}$, width $15 \mathrm{~mm}$.

Body structures: Head broad and short, eyes relatively small. Clypeus not known. Antennae about $15 \mathrm{~mm}$ long, composed of equal, long, cylindrical segments. Prothoracic lobes: about $7 \mathrm{~mm}$ long, with slightly undulated margin, veins about ten in number, cross veins very dense. Mesothorax about as long as metathorax.

Specimen I7-1 8 shows some additional body structures, which, for reasons mentioned above, I did not include into the account of this species. Fore wing: length $40.5 \mathrm{~mm}$, width I I $\mathrm{mm}$; hind wing: length $4 \mathrm{I} \mathrm{mm}$, width $\mathrm{I} 4.5 \mathrm{~mm}$. Venation of prothoracic lobes and the wings as in bonnieri, except that MA in the fore wing has longer 

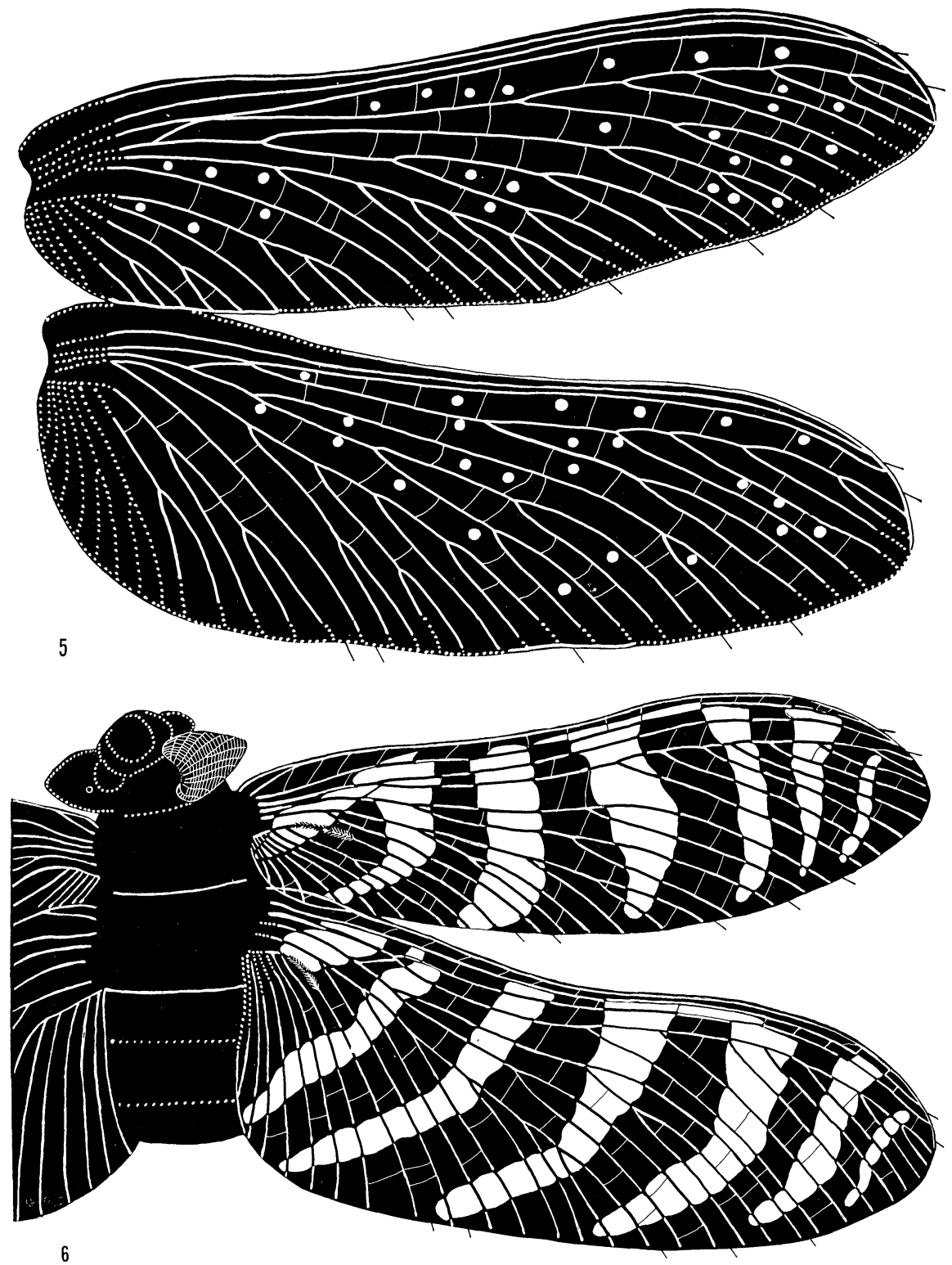

Figure 5. Homaloneura punctata Brongniart; specimen 17-13. Holotype. Figure 6. Homaloneura joannae Brongniart; specimen 18-5. Holotype. 
and more numerous branches, and that the apical part of the anterior margin is more convex. The cuticular thickening in specimen I7-I 8 is very well preserved. It is as prominent as the strongest vein, $R$, at the base of the wing. The surface of the cuticular thickening is sculptured by transverse striae. Head: length $3.2 \mathrm{~mm}$, width $5.8 \mathrm{~mm}$; eye length $2 \mathrm{~mm}$; clypeal length $3 \mathrm{~mm}$; prothoracic lobes length about $7.5 \mathrm{~mm}$. The abdomen is relatively slender, composed of very unequal segments; segments I-3 are shorter than the following ones, segments 5 and 7 longer than segments 4 and 6 . Each tergite has a distinct median line. The posterolateral angles of the tergites are prolonged.

Specimen $17-18$ is spectacular in having large eyes and clypeus, and a slender abdomen. The projecting of the posterolateral angles of the tergites was probably much less in the living insects than is apparent in the fossil, as a result of the separation of the segments during preservation.

$H$. bonnieri is close to elegans, but differs in the larger dimensions, the less narrowed apical part of the wings, with a less pointed apex, and in having the denser cross venation of the prothoracic lobes.

\section{Homaloneura punctata Brongniart \\ Figure 5}

Homaloneura punctata Brongniart, 1893: 319, pl. 17, fig. 13, pl. 18, figs. 3-4; Handlirsch, 1906: 108, pl. 12, fig. 4; Lameere, 1917: 147.

This species was based upon two specimens, according to Brongniart, but only one of these was figured. In the Paris Museum collection, I was able to find only the figured specimen, this consisting of the obverse of the fore and hind wings. Since Brongniart's figure does not show some parts of the wing margin and of the vein stems, which are very helpful for the interpretation of the wings, I have prepared a new figure, which also includes some additional structures not observed by Brongniart. The following account is based upon this one specimen.

Wings equal in length, the membrane relatively thick and darkcolored; small, rounded spots distributed as shown in Figure 5; cuticular thickenings at wing base unknown. Supporting cross veins running obliquely from the stem of $M$ to the very base of Rs. Fore wing: length $28 \mathrm{~mm}$, width $8.5 \mathrm{~mm}$. Posterior margin mainly lacking, but the margin seems to run parallel to the anterior one for most of its length; Rs with about five branches, the first of them forked; MA with I-2 branches, MP forked three or four times; $\mathrm{CuA}$ pectinate, with 4-5 branches, sometimes forked; $\mathrm{CuP}$ simple. 
Cross veins few, almost regular. Veins and cross veins lightly colored. Hind wing: length 28 , width about II $\mathrm{mm}$.

The venation indicates that punctata is related to the elegansbonnieri group more closely than to the joannae-ornata-lehmani group, since the fore wing lacks the very oblique position of branches of $\mathrm{CuA}$, and the main veins are more richly branched than in the last group of species.

\section{Homaloneura joannae Brongniart} Figure 6

Homaloneura joannae Brongniart, 1893: 320, pl. 18, fig. 5; Lameere, 1917 : 147.

Homaloneurites joannae Handlirsch, 1906: 107, pl. 12, fig. 1 .

This species was based by Brongniart upon specimen I8-5, which consists of the four wings, thorax, one prothoracic lobe, and vague outlines of head and clypeus. Handlirsch (1906) erected for this species a separate genus, Homaloneurites, on the basis of its veins being less branched; but that genus was placed in synonymy of Homaloneura by Lameere (1917), who did not accept as valid the characteristics given by Handlirsch. This is a difficult problem, and it is discussed below.

Handlirsch (1906) thought that Brongniart's specimen I7-15 was joannae as well, this fossil being erroneously designated by Brongniart as the reverse half of the type of ornata (I7-I6). Handlirsch was right that the specimen (I7-I5) was not the counterpart of the type specimen of ornata; it is not joannae either, but represents an undescribed species, named below lehmani.

In Brongniart's account of the specimen of joannae there are several mistakes in venational interpretation and in the description of the color pattern; also, the hind wing and the body structures were not illustrated. 'The following account gives these additional details as well as a review of those noted by Brongniart.

Wings equally long, membrane relatively strong and dark, with transverse light bands. Cuticular thickening extending on AI for a short distance as the vein curves towards the posterior margin. Supporting cross vein running obliquely from the stem of $M$ to the very base of Rs. Fore wing: length $22.5 \mathrm{~mm}$, width $5.7 \mathrm{~mm}$. Fore wing broadest at the beginning of the apical third, narrowing towards the base; apex rounded, about on the wing axis; anterior margin slightly concave; postcostal area triangular and small. Rs with seven simple branches; MA forked I-2 times; MP with a long fork; $\mathrm{CuA}$ with 4-5 pectinate branches; $\mathrm{CuP}$ simple; cubital branches 
very obliquely arranged; about eight simple anal veins; cross veins few and weak. Hind wing: length $25.5 \mathrm{~mm}$, width $9 \mathrm{~mm}$. Anterior margin more concave than in the fore wing. Anal area very much broadened just beyond the base, the inner angle of the wing nearly a right angle.

Body structures: Head apparently short and broad, with a rectangular clypeus. Prothoracic lobe: length $2.8 \mathrm{~mm}$, width $2 \mathrm{~mm}$; small and strongly sclerotized. Prothoracic veins about ten in number, cross veins very dense; mesothorax slightly shorter than the metathorax.

H. joannae is smaller than either elegans or bonnieri and has the wing membrane much thicker. The supporting structures in the wing are consequently less developed, the cuticular thickening extending for a very short distance on $A_{I}$, and there is only one supporting cross vein as well as a few weak cross veins. These same features are present in the ornata-lehmani group. Convergence of several morphological features is readily seen in this series of species. The head in joannat is short and broad, as it is in bonnieri, the shape of the prothoracic lobes and the venation are as in bonnieri, but the small size of the insect and the more heavy sclerotization is almost as in lehmani. The shape of the fore wings resembles lehmani most closely; the lack of small twigs on the veins and the rectangular shape of the anal area of the hind wing are much as in ornata; the obliquely arranged cubital veins are as in ornata and lehmani; the color patern is much as in lehmani; the cuticular thickening as in ornata. From these observations, it would seem that joannae, ornata, and lehmani might be considered as forming a separate genus, but at the present time it seems more advisable to leave them in a single genus until more is known about other species of the family.

\section{Homaloneura ornata Brongniart}

Figure 7

Homaloneura ornata Brongniart, 1893: 321, pl. 17, fig. 16; pl. 18, figs. 6-7; Handlirsch, 1906: 109, pl. 12, figs. 5-6; Lameere, 1917: 147; Handlirsch, 1921: 136, fig. 64 .

This species is based by Brongniart upon specimen $17-16$, the wings of which are shown enlarged on figures 6 and 7 of plate 18 . The specimen is a female, with two almost complete wings, with the abdomen showing cerci and the ovipositor, and there are vaguely preserved parts of the head and the thorax. As noted above, specimen I 7-I 5 was erroneously determined by Brongniart as the counterpart 


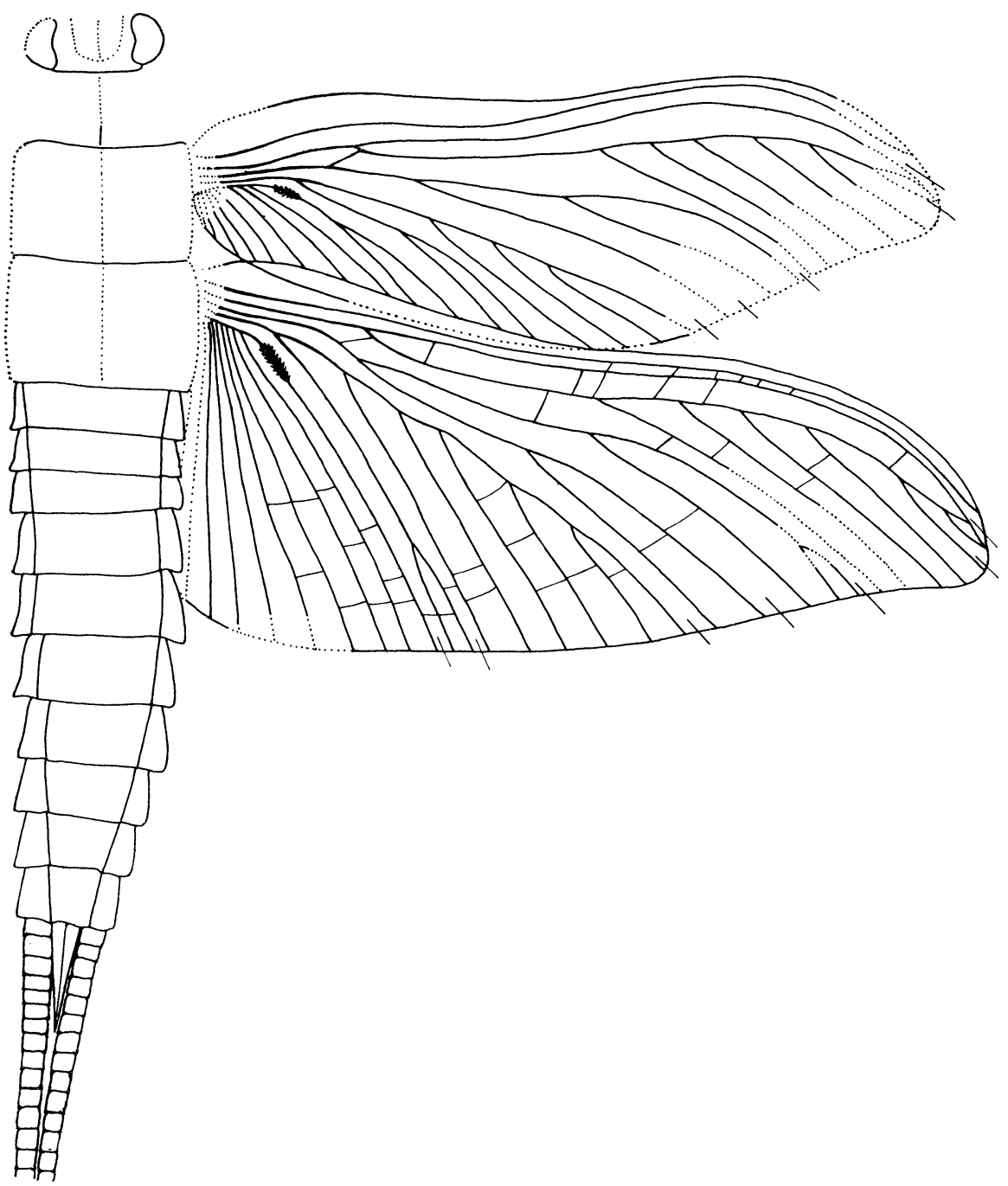

Figure 7. Homaloneura ornata Brongniart; specimen 17-16. Holotype. 
of this specimen of ornata, but it is not only not the same specimen, but it is a distinct species, described below as lehmani.

The type specimen of ornata is a reverse impression, with an indistinct pattern of color on the wings. In all probability, the wing membrane was dark with transverse light bands. The first three segments of the abdomen are narrow and rather indistinct; the ovipositor, in part hidden between the cerci, has previously been overlooked. Homaloneura ornata was figured in reconstruction by $\mathrm{Hand}-$ lirsch ( $192 \mathrm{I}$ ); the details shown by him are highly imaginary and probably incorrect; his figure, for example, shows the prothoracic lobes absent, which is almost certainly incorrect, since they are present in all other species of the genus.

Wings unequal in length the hind pair being longer; membrane relatively strong, dark, probably with transverse light bands. The cuticular thickening strengthening $A_{I}$ for a short distance at the point in which it bends towards the posterior margin; the supporting cross vein, r-m, weak, running obliquely from the stem of $M$ to the very base of Rs. Main veins with few branches. Fore wing: length about $20 \mathrm{~mm}$, width $7.5 \mathrm{~mm}$; broadest shortly beyond the midwing, markedly narrowing towards the base; apex pointed, directed posteriorly; anterior margin concave at about midwing; posterior margin with a convexly curved portion just before the apex; Rs with six simple branches, MA forked I-2 times; MP simple or with a long fork; $\mathrm{CuA}$ well developed, with 3-5 pectinate branches, which are obliquely arranged. CuP simple or forked; about eight simple anal veins; cross veins few and weak. Hind wing: length $23 \mathrm{~mm}$, width about $10.5 \mathrm{~mm}$; anal area very much expanded just beyond the wing base, the posterior margin forming nearly a right inner angle.

Body structures: Head with large, projecting eyes; clypeus apparently oval; prothoracic lobes unknown; mesothorax slightly shorter than the metathorax. Abdomen, length: I6 mm, relatively slender; tergites with projecting posterolateral angles; the segments I-3 very short, segment 6 longer than the others; ovipositor heavily sclerotized; longitudinal lateral lines on each tergite; cerci robust, completely covered by short hair.

H. ornata belongs to the group joannae-lehmani, all of these being small in size with simply-marked wings. Within this genus, ornata shows the highest modification in the wing shape, and has the most extensively broadened hind wings. 
Homaloneura lehmani, sp. nov.* Figure 8

The holotype of this species is Brongniart's I7-15, which was figured by him in 1893 as $H$. ornata; the specimen is in the Institute of Palaeontology in Paris, where I was able to make a careful examination of it. The specimen is very well preserved and shows the complete insect with four wings and many details of body structure. It is the only specimen of Palaeodictyoptera so far found which shows the beak in a bent condition; it suggests flexibility of the sheath and the tendency for the stylets to remain together. Another unusual structure is the presence of vestigial, almost scale-like, sclerotized prothoracic lobes, completely without venation. The clypeus is probably better preserved than that in any of the specimens of Palaeodictyoptera from Commentry, and it shows the very fine parallel striations which make a continuous series of bands.

Wings subequal in length, the hind pair somewhat longer. Wing membrane relatively strong, dark, with transverse light bands. Cuticular thickening strengthening $A_{I}$ for a short distance in the region of its curve towards the posterior margin. Supporting r-m cross vein weak, running obliquely from the stem of $M$ to the very base of Rs. Main veins with many short branches. Fore wing: length $23 \mathrm{~mm}$, width, $7.2 \mathrm{~mm}$; broadest shortly beyond midwing, narrowing towards the base; apex pointed, the apical part curved posteriorly; posterior margin slightly convex just before apex; Rs with 6-7 pectinate, simple branches; MA forking three times; MP forking 3-5 times; $\mathrm{CuA}$ with 3-5 pectinate branches, often forking; $\mathrm{CuP}$ with two forks; cubital branches in fore wing arranged very obliquely; about 5-6 anal veins, mostly forked; cross veins few, weak. Hind wing: length $23 \mathrm{~mm}$, width $9 \mathrm{~mm}$. Anal area abruptly expanding just beyond the wing base.

Body structures: Head I.5 mm long, broader than prothorax. Eyes very large, I.5 mm long, projecting. Clypeus oval, with median ridge and about eight pairs of parallel transverse striae. Preserved length of beak $4.3 \mathrm{~mm}$; prothorax narrowing anteriorly, about half the length of the mesothorax; prothoracic lobe length $2.3 \mathrm{~mm}$, width $2 \mathrm{~mm}$; prothoracic lobes vestigial, heavily sclerotized, cordate, the venation completely absent, but with a longitudinal median furrow, terminating just below the apex of the lobe. Mesothorax as long as metathorax. Abdomen shorter than the wings; first segment slightly

*Named in honor of Professor J. P. Lehman, Director of the Institut de Paléontologie, Paris. 


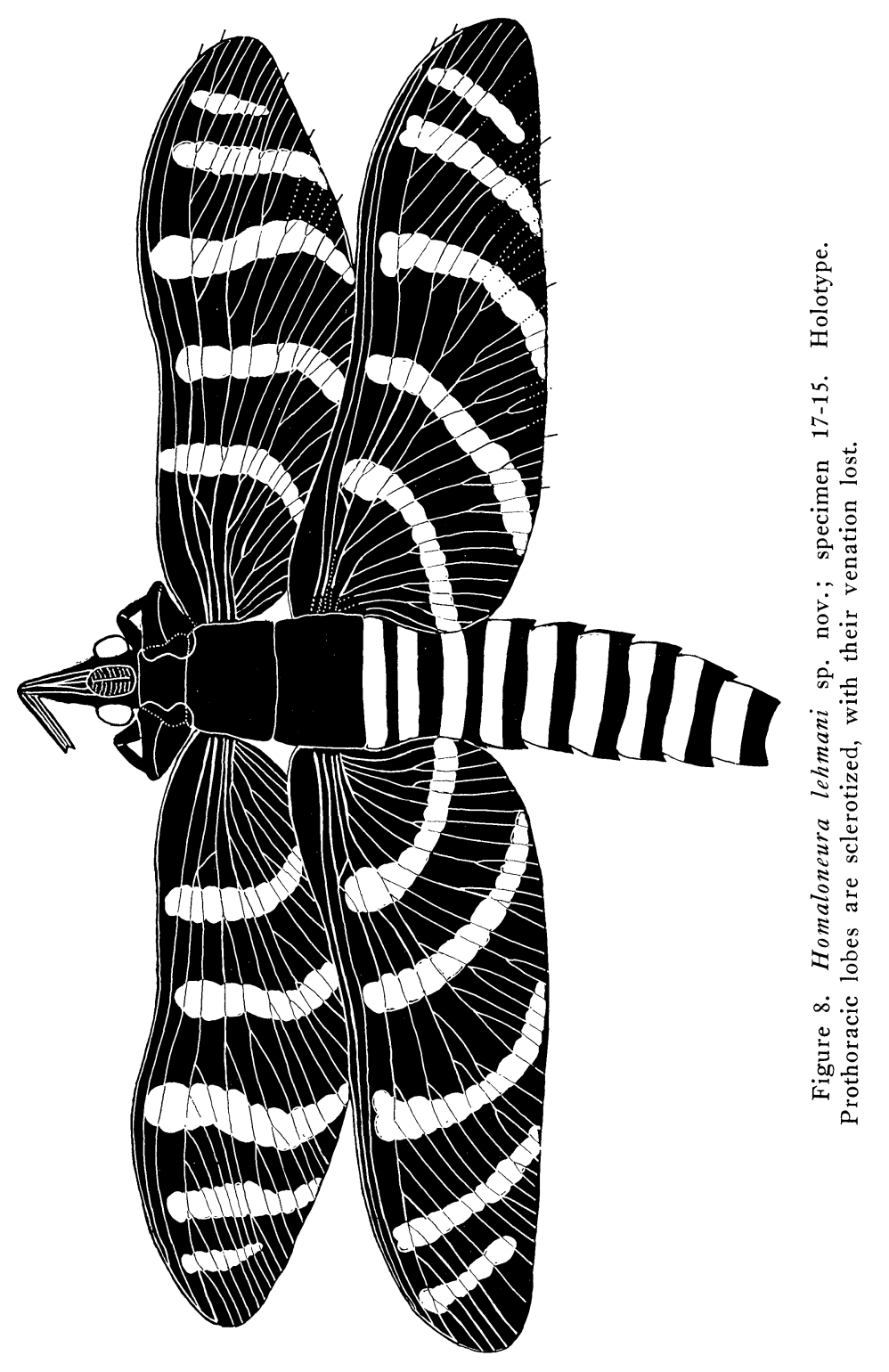


shorter than the following ones; posterolateral angles of tergites only slightly projecting; posterior half of tergites darkly pigmented.

This species is related to the group joannae-ornata, but differs in the presence of many short branches on the main veins and in the less pronounced enlargement of the hind wing, which is more similar to that of the elegans-bonnieri-dabasinskasi group. Within the genus this species has the most specialized prothoracic lobes, which are the smallest and most sclerotized and which, in contrast to those of other species, do not show any traces of venation.

\section{Homaloneura bucklandi Brongniart Figure 9}

Homaloneura bucklandi Brongniart, 1893: 320, pl. 17, fig. 14; pl. 18, fig. 2; Handlirsch, 1906: 108, pl. 12, fig. 3; Handlirsch, 1919: 20; Lameere, $1917: 147$.

This species is based by Brongniart upon specimen I7-I4 (also figured on $\mathrm{pl}$. 18, fig. 2), which represents a fore wing lacking the base. The insect seems to be rather remote from all others in the genus, showing more numerous and less irregular cross veins. Unfortunately, I could not locate the type specimen in the Paris Museum. The following account is based upon the photograph made by Dr. Carpenter in 1938 and upon Brongniart's original description and Lameere's revisional study. At present, I prefer to leave bucklandi with the genus Homaloneura, but feel that this classification is dubious, and that this species might turn out to represent a distinct genus.

Wings probably dark; cuticular thickening unknown; supporting $m-r$ cross vein running obliquely from the stem of $M$ to $R$. Fore wing: length $29 \mathrm{~mm}$, width $9 \mathrm{~mm}$ (according to Brongniart, p. 320); almost uniformly broad in the proximal half; anterior margin slightly concave beyond the basal third; posterior margin slightly undulated in the region of $\mathrm{CuP}$ and $\mathrm{CuA}$; Rs with about six branches; $\mathrm{MA}$ with one short branch; MP with about five branches; $\mathrm{CuA}$ with three branches; $\mathrm{CuP}$ with a short fork; anal area with about 6-8 veins, mostly forked; cross veins numerous, irregular, sometimes probably with anastomoses.

II. bucklandi differs from all other species of the genus by the numerous and irregular cross veins; MA has fewer branches than punctata and joannae, and CuP has a simple fork as in bonnieri.

Genus Spilaptera Brongniart

Spilaptera Brongniart, 1885: 63; Brongniart, 1893: 337; Brauer, 1886: 110;

Handlirsch, 1906: 102 ; Bolton, 1917: 53; Handlirsch, 1919: 20. 

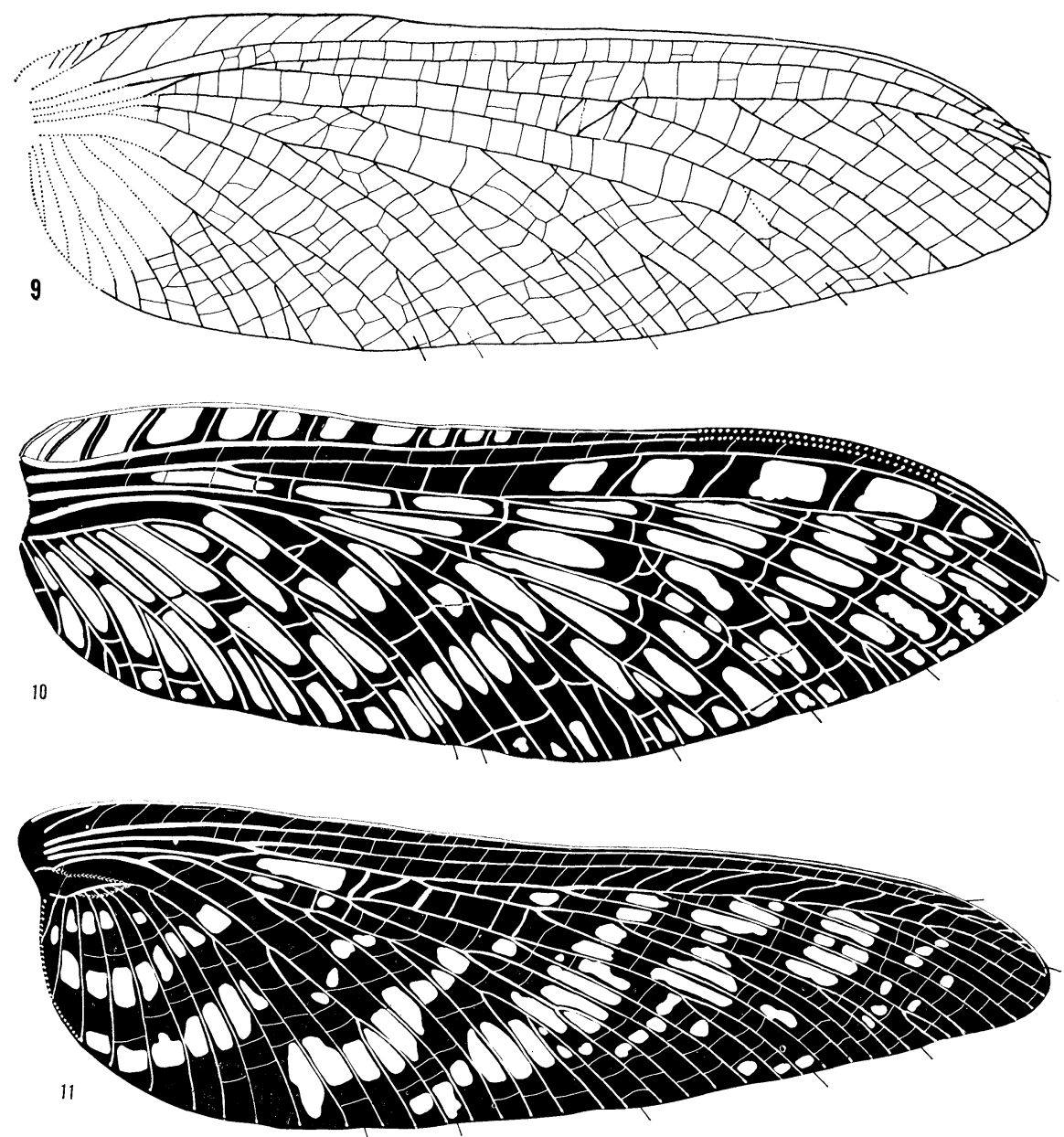

Figure 9. Homaloneura bucklandi Brongniart; specimen 17-17; fore wing. Holotype.

Figure 10. Spilaptera packardi Brongniart; specimen 20-7; fore wing. Holotype.

Figure 11. Becquerelia superba Brongniart; specimen 19-1; hind wing. Holotype. 
Type species: Spilaptera packardi Brongniart, I885 (SD, Handlirsch, 1922).

The genus Spilaptera was erected by Brongniart for three species, packardi, libelluloides, and vetusta. In I893, meunieri was added to the genus. Handlirsch (1906) made a new genus, Epitethe for meunieri on the basis of more numerous branches of the main veins, and this genus was accepted by Lameere (I9I7). Unfortunately, I was unable to find the type specimen of vetusta in the Museum and Dr. Carpenter failed to find it in 1938; for that reason I am not including vetusta in this paper.**

Brongniart (1893), Handlirsch (1906), and Lameere (1917) were of the cpinion that Sc in Spilaptera does not extend much beyond the middle of the wing. This is not correct, however, as in the type species packardi and in libelluloides after removal of the covering matrix, the costa can be seen terminating near the wing apex. It has also proved possible to excavate a part of the hind wing in libelluloides, the hind wing not previously having been known in the genus.

The wings in Spilaptera are of almost equal length. Wing membrane with color markings; hind wing broader in the proximal half than the fore wing, but with a similar venation. Cuticular thickening and supporting veins missing. The anterior margin only slightly concave. RI without terminal branches; R-Rs area broad with a series of several strong oblique cross veins; Rs with only 4-5 branches; M free from Rs; MA with several branches; MP forked several times; $\mathrm{CuA}$ pectinate; $\mathrm{CuP}$ simple or forked; cross veins few, with a tendency to make rows in the apical third of the wing.

Spilaptera resembles Homaloneura by having few cross veins and by the general wing structure, but it lacks both the thickenings and supporting veins. These are perhaps replaced in this genus by a few strong cross veins, which tend to be surrounded, and probably supported, by pigmented areas. The cross veins are very typical in the R-Rs area, being sigmoidal in shape in both known species, Spilaptera packardi Brongniart and Spilaptera libelluloides Brongniart.

The species of Spilaptera present in the Commentry shales are $S$. packardi Brongniart, 1885 and $S$. libeliuloides Brongniart, 1885.

*The small wing fragment designated by Bolton (1917: 53) as representing a new species, Spilaptera sutcliffei, is not recognizable even to the family level and is herein assigned to the Palaeodictyoptera incertae familiae. 


\section{Spilaptera packardi Brongniart}

Figure Io

Spilaptera packardi Brongniart, 1885: 63, pl. 5, fig 1; Brongniart, 1893: 338, pl. 20, fig. 7; Handlirsch, 1906: 102, pl. 11, fig. 16.

This species is based by Brongniart upon specimen 20-7, which is a well preserved fore wing with a perfect color pattern.

Fore wing: length $53 \mathrm{~mm}$, width $\mathrm{I} 6.5 \mathrm{~mm}$, broadest at midwing. Light spots, mostly oval in shape, occur between the cross veins as shown in figure Io. Anterior margin concave. Posterior margin parallel in the proximal half with anterior, then concave. Apical part abruptly narrowing, the apex pointed and located about on the wing axis. Postcostal area with two simple veins originating on Sc. Subcostal area broad in the proximal third, very narrow distally. R-Rs area with only about 4-5 strong cross veins in its distal half; Rs with about five very oblique simple branches; MA with four short branches; MP forked about three tines; $\mathrm{CuA}$ with a series of about six branches; CuP simple; anal area relatively large, with about eight branches, sometimes forked. Cross veins very few, strong, mostly curved, forming rows.

$S$. packardi differs from iibelluloides in its color pattern, the shape of the fore wing, the simple $\mathrm{CuP}$, and the presence of fewer cross veins.

\section{Spilaptera libelluloides Brongniart \\ Figure 12}

Spilaptera libelluloides Brongniart, 1885: 63; Brongniart, 1893: 339 pl. 20, fig. 8; Handlirsch, 1906: 103, pl. 11, fig. 17.

This species is based upon specimen $20-8$, originally consisting of part of the fore wing and a small fragment of the hind wing. After I had removed more of the matrix, all four wings, with almost complete venation, could be seen. The body, which was partially described by Brongniart ( $1893: 340$ ) is insufficiently preserved for study.

Wings of equal length, with narrow dark bands, about seven in number, irregular and more concentrated in the apical part of the wing, as shown in figure II. Anterior margin concave, the posterior margin as a whole is moderately concave and very slightly undulated. Fore wing: length $57 \mathrm{~mm}$, width $2 \mathrm{I} \mathrm{mm}$, broadest at the end of the proximal third; apical part abruptly narrowing and short, the apex pointed and located on the wing axis. Subcostal area not markedly broad in the proximal third. R-Rs area with about 5-6 strong cross veins, surrounded by color markings in the distal half of the wing; 


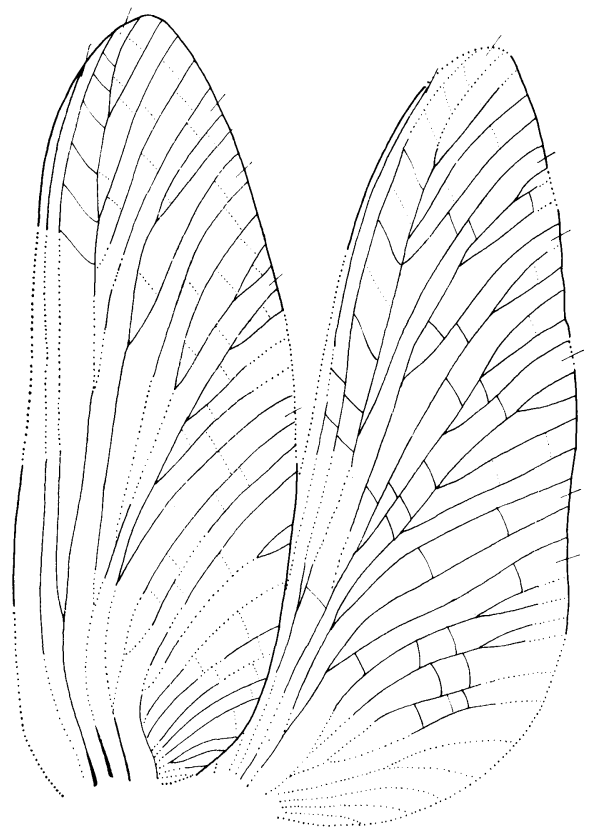

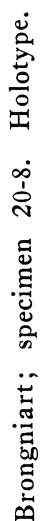

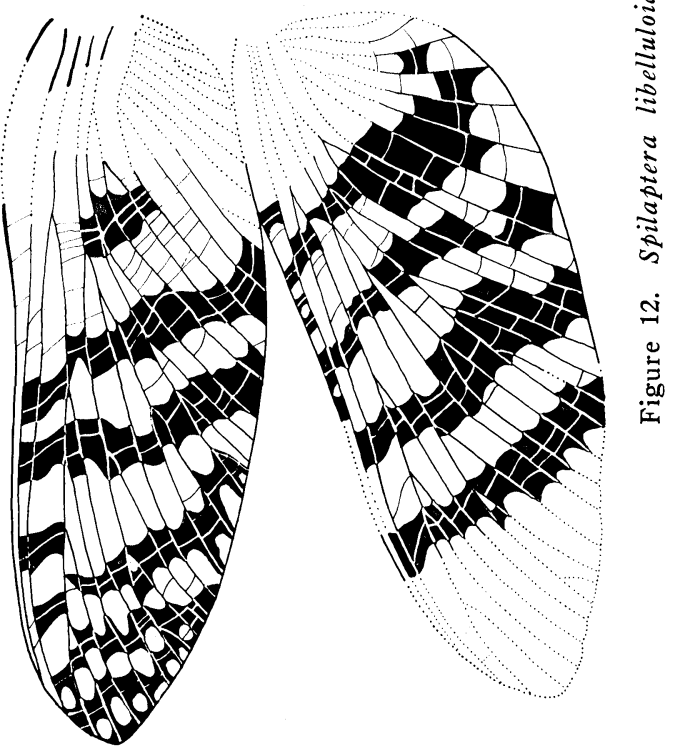


Rs with about four simple branches; MA with 2-3 branches; MP forked 2-4 times; $\mathrm{CuA}$ with a series of four branches; $\mathrm{CuP}$ forming a long fork; anal area with about eight veins, mostly simple. Cross veins are not numerous and are not forming rows. Hind wing: length $57 \mathrm{~mm}$, width $22.6 \mathrm{~mm}$. Hind wing not much broadened, but with a rounded anal area.

$S$. libelluloides differs from packardi as previously mentioned.

\section{Genus Becquerelia Brongniart}

Becquerelia Brongniart 1893: 356; Handlirsch, 1906: 105; Lameere, 1917: 152.

Pseudobecquerelia Handlirsch, 1919: 24.

Type species: Becquerelia superba Brongniart, I893 (SD, Handlirsch, I906).

This genus was erected by Brongniart in 1893 for four species, superba, tincta, grehanti, and elegans. Handlirsch ( 1906) designated superba as the type species and questioned the generic position of grehanti and indicated his uncertainty about elegans, because of its fragmentary nature. In 1919, however, Handlirsch erected the genus Pseudobecquerelia for elegans, although he put it in the Palaeodictyoptera incertae sedis. Lameere ( I917: I52) suggested that grehanti be placed in Epitethe Handlirsch, as previously noted, and he considered elegans as a true Becquerelia.

In this paper, superba and tincta are considered to be very closely related; they may eventually turn out to be conspecific. Elegans is a small fragment, but probably belongs to Becquerelia, as it was considered by Lameere. Grehanti, on the other hand, is here designated as the type species of a new genus, Tectoptilus. The following are the characteristics of Becquerelia, as they are indicated in superba and tincta; included are some features not previously noted.

Wings dark colored, with light transverse bands; cuticular thickening $\mathrm{V}$-shaped, its apex on $\mathrm{Ar}_{\mathrm{I}}$; anterior margin only slightly concave; postcostal area small, with a single vein. Sc long, terminating somewhat before apex; RI with terminal branches; in the R-Rs area there are numerous long, oblique cross veins; Rs pectinate, with six branches; $M$ fused for a long distance with the stem of Rs; MA pectinate; MP forking several times; $\mathrm{CuA}$ pectinate; $\mathrm{CuP}$ forked; cross veins numerous, simple, but somewhat irregular.

Becquerelia shows the same type of cuticular thickening as Homaloneura elegans and bonnieri, but in place of the extra strengthening cross vein between $\mathrm{M}$ and $\mathrm{R}-\mathrm{Rs}$, as in Homaloneura, MA functions 
as the strengthening vein by fusing with Rs at its very beginning. Except for this fusion of MA with Rs, Becquerelia is scarcely distinct from Palaeoptilus, both in venation and in coloration.

The known Commentry species of Becquerelia are superba Brongniart and tincta Brongniart; elegans, as noted above, probably belongs in this genus, but its fragmentary condition does not allow further description.

\section{Becquerelia superba Brongniart \\ Figure II}

Becquerelia superba Brongniart, 1893: 357, pl. 19, fig. 1; Handlirsch, 1906: 105, pl. 11, fig. 22.

This species is based upon specimen I9-I, consisting of a well preserved hind wing with a clearly preserved color pattern.

Hind wing: length $85 \mathrm{~mm}$, width $27 \mathrm{~mm}$; broadest just beyond the base; anterior part of cuticular thickening running from the beginning of $\mathrm{Cu}$ obliquely to the bend of $\mathrm{AI}$; posterior part of the thickening following AI for some extent, then parallel to it until the bend in $A_{1}$; several supporting cross veins are present between the base of $\mathrm{MA}$ and $\mathrm{R}+\mathrm{Rs}$; color markings forming numerous light elongate spots, arranged into about eight transverse bands; apical part of wing elongate, the apex rounded, directed posteriorly; anal area somewhat enlarged, with about 12 oblique cross veins in its distal half; Rs with six very oblique, simple branches; MA with about four long branches; MP forked about five times; $\mathrm{CuA}$ with a series of five long branches; CuP forked twice; anal area with nine simple branches; cross veins less numerous in the anal area, where they form rows.

Becquerelia superba (hind wing) differs from tincta (basal part of fore wing) in having the first fork of MP directed more posteriorly, by the presence of long forks on the anal veins, and by the patches of additional small light spots near the base of the wing, although the latter might be an individual trait, rather than specific.

\section{Becquerelia tincta Brongniart}

Figure 13

Becquerelia tincta Brongniart, 1893: 362, pl. 20, fig. 3; Handlirsch 1906: 105, pl. 11, figs. 23-24.

This species is based upon specimen 20-3, consisting of the proximal third of a fore wing. The color pattern is not distinct.

Fore wing: length of fragment $24 \mathrm{~mm}$, width $25 \mathrm{~mm}$; light, elongate spots forming transverse bands; cuticular thickening apparently 

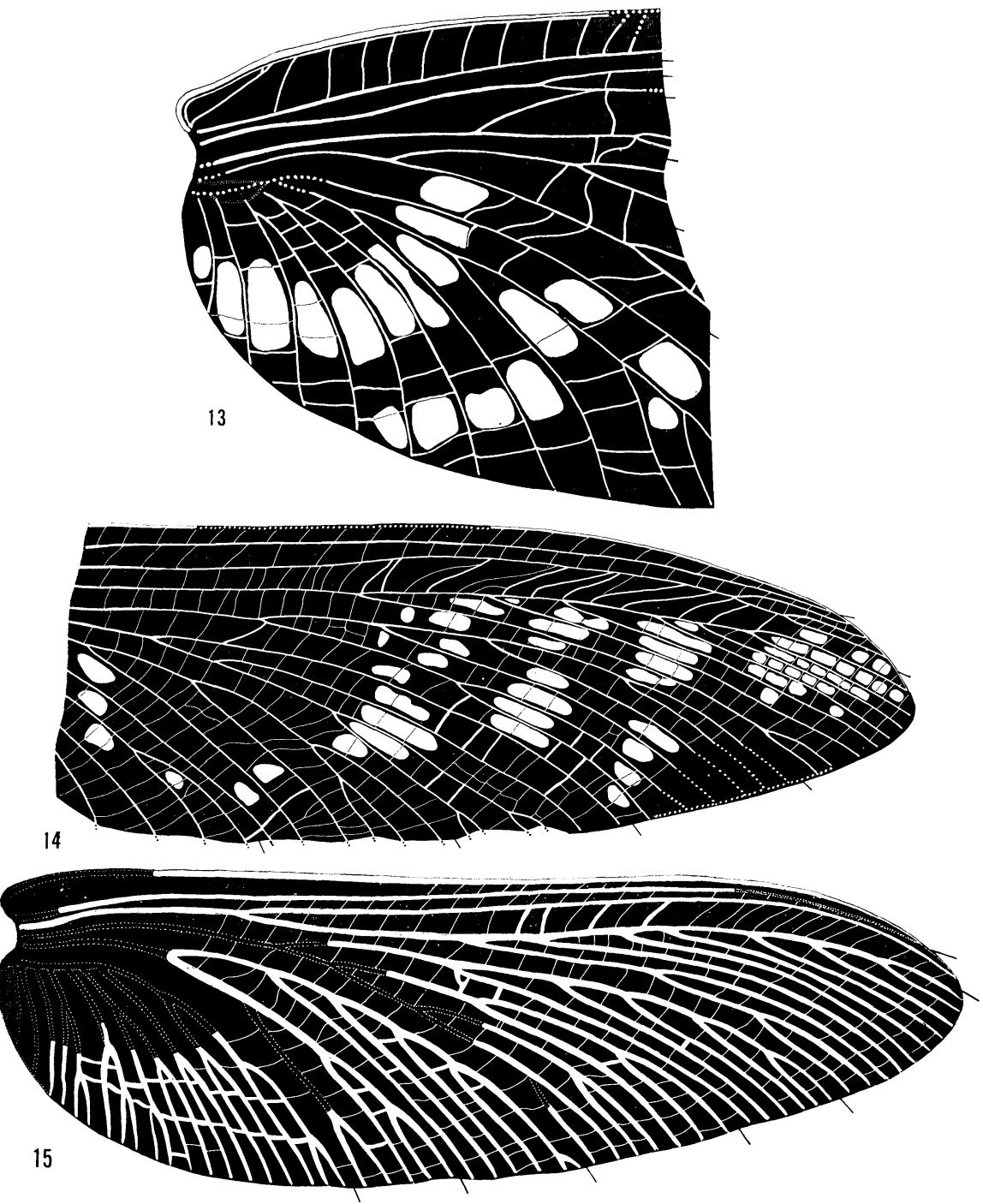

Figure 13. Becquerelia tincta Brongniart; specimen 20-3; fore wing. Holotype.

Figure 14. Palaeoptilus brullei Brongniart; specimen 19-15; fore wing. Holotype.

Figure 15. Epitethe meunieri (Brongniart); specimen 19-5; hind wing. Holotype. 
the same as in superba; wing narrowing towards the base; postcostal area triangular, narrow; subcostal area in the form of a band near the base; $\mathrm{CuP}$ with at least two branches; anal area large, with only five veins, but with several long forks; cross veins numerous, simple, sometimes curved.

Becquerelia tincta may be conspecific with superba, though it appears to differ in having the origin of the first fork of MP more proximal, and in having several long forks of the anal veins. The color pattern is similar to that of Homaloneura dabasinskasi Carpenter from the Westphalian nodules of Illinois, and of Palaeoptilus brullei Brongniart from the Commentry shales.

\section{Genus Palaeoptilus Brongniart}

Palaeoptilus Brongniart, 1893: 352; Handlirsch, 1906: 101.

Type species: Palaeoptilus brullei Brongniart, I893 (OD).

This genus is montoypic, being erected by Brongniart for a single species close to Becquerelia elegans. The following account, which is based upon a study of the type specimen, includes more details of venation than have previously been noted.

Wings dark colored with light spots arranged in transverse bands; cuticular thickening unknown; Sc terminating somewhat before the apex; RI with terminal branches; in the R-Rs area there are numerous long, oblique cross veins; MA is free from the stem of Rs; Rs and MA pectinate; MP forked several times; $\mathrm{CuA}$ pectinate; $\mathrm{CuP}$ forked. Anal area unknown. Cross veins numerous, simple, but somewhat irregular.

Except for the lack of fusion of MA with the stem of Rs, Palaeoptilus is similar to Becquerelia, although the shape of the cuticular thickening is not known. The general venational pattern, the cross veins, and the large R-Rs area with its oblique cross veins are reminiscent of Epitethe.

The type species is the only one known in the Commentry shales.

\section{Palaeoptilus brullei Brongniart}

Figure 14

Palaeoptilus brullei Brongniart, 1893: 353, pl. 19, fig. 15; Handlirsch, 1906: 102, pl. 11, fig. 15.

This species is based upon a single specimen, Brongniart's I9-15, which is a well preserved fore wing lacking the basal quarter and the posterior margin. 
Fore wing: length of fragment $6 \mathrm{r} \mathrm{mm}$, width $22 \mathrm{~mm}$; light spots elongate, arranged into irregular bands, more dense in the apical part; the anterior margin slightly convex in the distal half; apical part of wing not elongate, the apex moderately pointed, arranged on wing axis. Subcostal area narrow in the distal two-thirds of wing; $\mathrm{R}_{\mathrm{I}}$ with two long terminal branches; r-rs area broad, with a series of thin, very oblique cross veins; Rs with six oblique simple veins; MA with four long branches; MP forked about three times; $\mathrm{CuA}$ with a series of four branches; CuP forked three times; cross veins numerous, simple, but slightly irregular.

Palaeoptilus brullei is similar to Recquerelia superba in having terminal branches on $\mathrm{Rr}$, in the broadened $\mathrm{r}$-rs area with its oblique cross veins, and in the color pattern and venation, but differs in the absence of a fusion of MA with Rs.

\section{Genus Epitethe Handlirsch}

Epitethe Handlirsch, 1906: 103; Lameere, 1917: 150; Handlirsch, 1919: 20. Type species: Spilaptera meunieri Brongniart (OD).

This genus was erected for meunieri on the basis of its more numerous branches of the main veins; the genus was accepted by Lameere.

Wing membrane dark; cuticular thickening unknown; the anterior margin almost straight; posterior margin slightly undulated; branches of main veins numerous, markedly parallel; Sc long, terminating shortly before apex (not terminating before midwing, as described by Handlirsch); RI without terminal branches; MA free from Rs; Rs with seven branches; MA pectinate; MP forked several times; $\mathrm{CuA}$ pectinate; $\mathrm{CuP}$ forked several times. Anal area with many forked branches. Cross veins numerous, mostly irregular.

This genus differs from all others in the family by the pattern of dense and parallel branches of the veins; this trait and the pattern of cross veins recalls the genus Tectoptilus and Palaeoptilus. However, with the absence of other details, such as the nature of the cuticular thickening at the base of the wing, the relationship of this genus is uncertain.

Only the type species is known from the Commentry shales.

\section{Epitethe meunieri (Brongniart) \\ Figure 15}

Spilaptera meunieri Brongniart, 1893: 343, pl. 19, fig. 5 .

Epitethe meunieri, Handlirsch, 1906: 103, pl. 21, fig. 19; Lameere, 1917: 150. 
This species is based upon Brongniart's specimen 19-5, a hind wing lacking the basal part.

Wings dark, with broad, light veins and cross veins. Hind wing only moderately broadened, broadest at about the first third; length $48 \mathrm{~mm}$, width $16 \mathrm{~mm}$; anterior margin almost straight, posterior margin undulated; apical part relatively broad, apex rounded, located at about the wing axis; r-rs area slightly broadened, with numerous, weak and somewhat oblique cross veins; Rs with seven branches, the first being forked twice; MA with five simple, long branches; MP with six forks; $\mathrm{CuA}$ with a series of four long simple branches; $\mathrm{CuP}$ forked four times. Anal area large, with nine anal veins, most of them forked; cross veins numerous, regular, less dense in the anal area, broader and forming rows.

This species has a unique coloration among the Spilapteridae. The apparent width of the veins is probably due to the accompanying white strips along the veins, rather than to the veins themselves.

\section{Genus Tectoptilus gen. nov.*}

Type species: Becquerelia grehanti Brongniart.

The type species of this genus, grelianti, is known only from a single specimen, number 20-4 of Brongniart's I893 monograph. Although he placed the species in Becquerelia, this assignment was questioned by Handlirsch (1906) and Lameere (1917), who referred it to the genus Epitethe Handlirsch. In the course of my study of the fossil, I have noted additional features which separate the insect from all genera which have been established. In the Museum collection, I have also found an unfigured specimen which seems to be conspecific with grehanti (figure 17 ). This specimen, being much better preserved than the type, contributes much information about the fore wings and certain body structures, which have been used in the following account.

Wings dark with a light pattern. Cuticular thickening Y-shaped, extending into the area of $\mathrm{CuP}$ and $\mathrm{Ar}$. Anterior margin slightly concave. The termination of RI unknown but Rs pectinate, with few branches; MA with several branches, MP richly branched; $\mathrm{CuA}$ pectinate, $\mathrm{CuP}$ with an unusual number of branches, extending over a large area. Anal area with many branches also. Cross veins numerous, simple or rarely irregular and anastomosed; posterior mar-

*This generic name is based on the Greek word (tekton) for a carpenter and is used in honor of Professor F. M. Carpenter, Harvard University. 

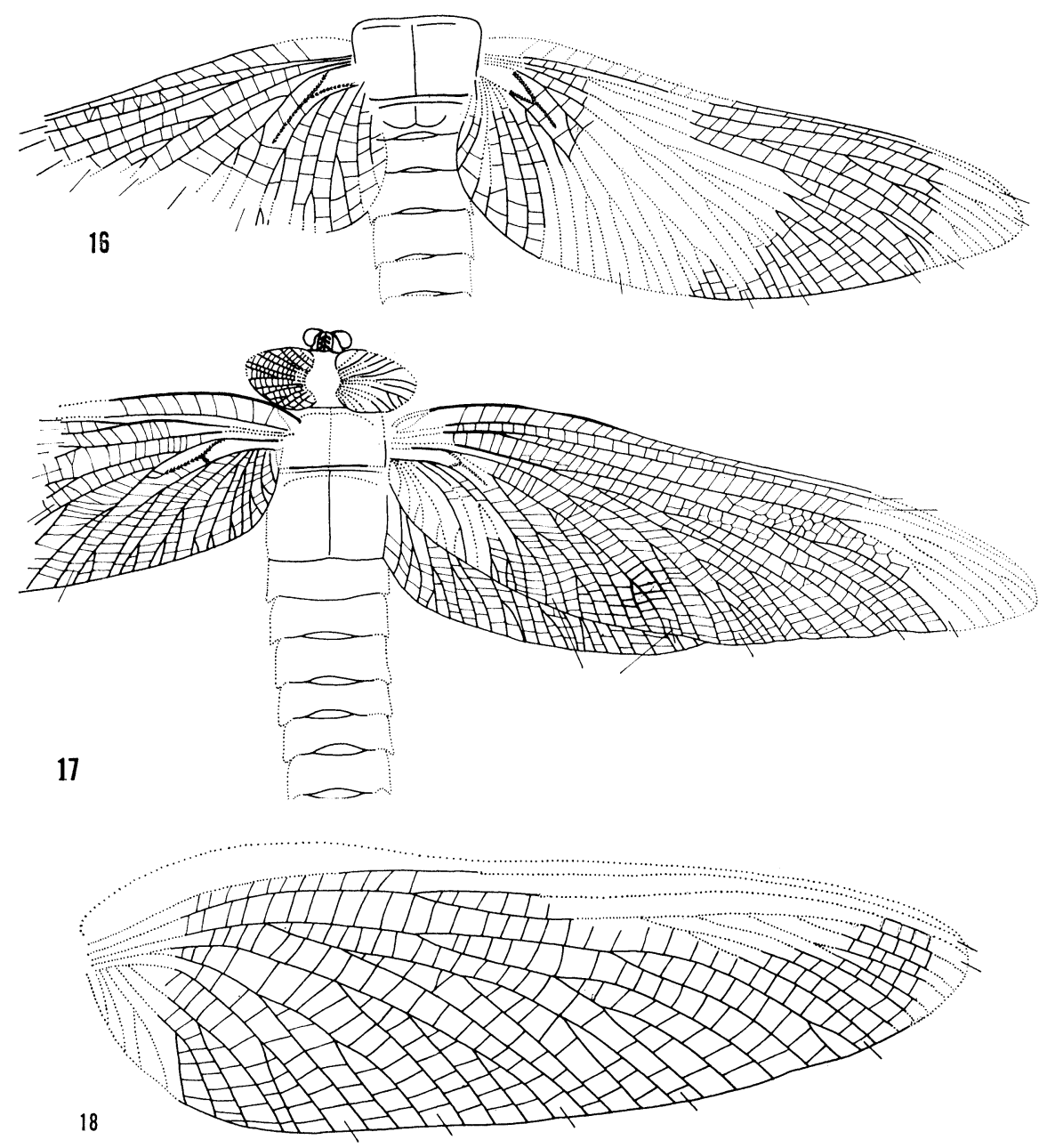

Figure 16. Tectoptilus grehanti(Brongniart); specimen 20-4; hind wings. Holotype. Originally described as Becquerelia grehanti Brongniart, 1893.

Figure 17. Tectoptilus grehanti (Brongniart); undescribed specimen also in collection of Paris Institute.

Figure 18. Spiloptilus ramondi (Brongniart); specimen 19-14; fore wing. Holotype. 
gin somewhat undulated. Hind wing little known, not greatly broadened.

Body structures: Head small, much narrower than the prothorax, eyes prominent. Prothoracic lobes cordate, with radiating veins and numerous cross veins; metathorax very broad, longer than the mesothorax.

This genus is apparently related to other genera of this family with numerous cross veins, such as Palaeoptilus, Spiloptilus, Epitethe, and Becquerelia. The absence of the distal part of $\mathrm{R}_{\mathrm{I}}$ in grehanti prevents precise comparison with Palaeoptilus, and the absence of the cuticular thickening of the wing in Palaeoptilus, Epitethe and Spiloptilus prevents satisfactory comparison with those genera. However, the genus Tectoptilus differs from all other spilapterid genera in having the $\mathrm{Y}$-shaped cuticular thickening, which extends between $\mathrm{CuP}$ and $\mathrm{AI}_{\mathrm{I}}$, and in having an unusually broad area of $\mathrm{CuP}$, with many branches. This last character, as well as the fully developed $\mathrm{MA}$ and the presence of numerous cross veins resembles the structure of the Fouqueidae, although the other features known are spilapterid in nature. The genus Tectoptilus, in this way, seems to be somewhat intermediate between the Fouqueidae and the Spilapteridae. At the present state of our knowledge, it seems to be impossible to draw a strict line between these two families.

\section{Tectoptilus grehanti (Brongniart)}

Figures 16 and 17

Becquerelia grehanti Brongniart, 1893: 359, pl. 20, fig. 4; Handlirsch 1906: 106, pl. 11, fig. 25; Lameere, 1917: 152.

This species, based upon specimen 20-4, shows two hind wings, the metathorax, and five segments of the abdomen; in addition, another, previously undescribed specimen is contained in the collection of the Museum, this showing the fore wings in part, the head (with eyes and clypeus), prothoracic lobes, and the thorax and six segments of the abdomen. On the basis of the similarity of venation and the nature of the cuticular thickening, I consider this conspecific with the type of grehanti; this may be the specimen which Lameere (1917: 155) mentioned as an additional specimen of Fouquea needhami Lameere. The following account is based upon both of these specimens.

Wings: dark with light maculations; fore wing: length $58 \mathrm{~mm}$, width $20 \mathrm{~mm}$, broadest slightly before the midwing; narrowed in the basal part with distal part elongate; $r$-rs area not broadened, with 
dense series of slightly oblique cross veins; MA with two branches, MP richly branched, forking about eight times; $\mathrm{CuA}$ with three branches; $\mathrm{CuP}$ forking six times; anal area long and narrow, with six to eight forking branches; cross veins numerous, often curved, irregular and sometimes anastomosed. Hind wing: length $62 \mathrm{~mm}$, width $24 \mathrm{~mm}$, broadest at the end of the first third, with moderately rounded anal area.

Body structures: Head with reniform eyes, extending nearly to the clypeus; length of clypeus $3 \mathrm{~mm}$, width $\mathrm{r} .3 \mathrm{~mm}$, rectangular in form, rounded anteriorly; transverse ridges oblique in the posterior region of the clypeus. Prothoracic lobes with about eleven veins, sometimes forked, and with numerous cross veins. Prothorax as long as the mesothorax, metathorax 1.5 times longer than mesothorax. Abdomen slenderer than metathorax, with segments I-2 only a little shorter than the longest one, segment 3.

T. grehanti is unusual in having a very small head, the reniform eyes and the very large metathorax.

\section{Genus Spiloptilus Handlirsch}

Spiloptilus Handlirsch, 1906: 100.

Type species: Graphiptilus ramondi Brongniart (OD).

Although Handlirsch was undoubtedly correct in establishing a separate genus for ramondi, he was incorrect in placing it in the family Graphiptilidae; this error was made because he was under the impression that MA in ramondi was unbranched. The generic characters are revised here on the basis of my examination of the type specimen of ramondi, in which I have been able to determine more details about the structure of the Rs and anal area.

Wing: membrane dark; cuticular thickening unknown; supporting cross veins not present; anterior margin, Sc and R I unknown; Rs diverging from $R_{I}$ just beyond the first third of the wing, with a few branches, which may be forked; MA well developed, forking several times; MP with several branches; both $\mathrm{CuA}$ and $\mathrm{CuP}$ pectinate; anal area relatively small; cross veins numerous, simple, regular in form and equally distributed.

Spiloptilus differs from all other genera in the more distal origin of Rs, but detailed comparison with other genera is not possible because of the poor preservation of the type, the only known species of Spiloptilus. 


\section{Spiloptilus ramondi (Brongniart) \\ Figure I 8}

Graphiptilus ramondi Brongniart, 1893: 351, pl. 19, fig. 14.

Spiloptilus ramondi, Handlirsch, 1906: 102, pl. 11, fig. 14.

This species is based upon specimen I9-I 4 , which is a badly preserved fore wing, lacking the base and the anterior margin. The venation is not clearly visible, but can be determined to some extent with the use of glycerin.

Fore wing: length $60 \mathrm{~mm}$, widest at the end of the first quarter; posterior margin slightly undulated; apical part abruptly narrowed; Rs with five branches, which may be forked; MA occupying a large area, forked about five times; MP with a series of three branches; $\mathrm{CuA}$ with four branches, $\mathrm{CuP}$ forked twice; anal area relatively small, with about five branches, mostly forked. Cross veins equally distributed.

\section{Genus Lamproptilia Brongniart}

Lamproptilia Brongniart, 1885: 63; Brauer, 1886: 109; Handlirsch, 1906: 110; Handlirsch, 1919: 21; Laurentiaux, 1953: 422.

'Type species: Lamproptilia grandeuryi Brongniart, I885 (OD).

In his I 893 monograph, Brongniart added a second species, stirrupi, and established for the two species a separate subfamily which he termed the "Lamproptilida." Handlirsch ( 1906) raised this to family level on the basis of the very broad hind wings. Although this family has been accepted by subsequent workers, its close relationship to the Spilapteridae has frequently been noted. Since the body parts of Lamproptilia are unknown, we can base our conclusions only on the wing structure, which does not show any features justifying assignment to a separate family. Such characteristics as the broad hind wings occur in some other spilapterids in which the wings are even broader, and the form of the posterior margin of the hind wing as well as the color pattern of the wings falls well within the range of variation within the family Spilapteridae.

The species which Brongniart described as stirrupi is undoubtedly a spilapterid but it does not show enough of the venation to enable generic assignment; it is herein placed within the spilapterids, but without generic position.

The following are the characteristics which are suggested for the genus Lamproptilia. Wings: membrane dark, with a complicated color pattern, concentrated mainly in the distal half; cuticular thickening absent; wings subequal, the hind pair shorter than the front pair. Fore wing noticeably short and broad, the hind wing with 
pronounced convex curvature along the posterior margin between $\mathrm{CuA}$ and $\mathrm{CuP}$; subcostal area narrow; $\mathrm{Sc}$ long; $\mathrm{R}_{\mathrm{I}}$ without terminal branches; Rs long, originating in the basal third, with 2-3 branches; MA forked several times, MP somewhat more extensively branched; $\mathrm{CuA}$ giving rise to several branches; $\mathrm{CuP}$ forked several times; anal area with many forked branches.

Lamproptilia differs from all other spilapterid genera in the very broad and short wings, and in having the prominent anal-cup lobe in the hind wing. The venation, characterized by numerous cross veins, is suggestive of that of Tectoptilus, Palaeoptilus, etc.

\section{Lamproptilia grandeuryi Brongniart}

Figures 19 and 20

Lamproptilia grandeuryi Brongniart, 1885: 63, pl. 3, fig. 1; Brongniart, 1893: 345, pl. 35, figs. 7-8; Handlirsch, 1906: 110, pl. 12, fig. 8; Handlirsch, 1919: 21; Handlirsch, 1921: 137, fig. 65; Lameere, 1935: 175 ; Laurentiaux, 1953: 422, fig. 20.

This species was based on a single specimen ( I9-8), consisting of an exceptionally well preserved fore and hind wing with striking color pattern. Unfortunately, only the reverse half of the fossil could be found in the collection of the Museum; this shows the color much less clearly than the obverse, as is often the case with the Commentry insects. Fortunately, the color markings are very well shown in a photograph of the obverse made by Professor Carpenter in 1938. A drawing of the wings of this species, based on both obverse and reverse, has been published by Laurentiaux ( 1953, fig. 20). The following account is based upon the reverse of the type specimen.

Fore wing: length $75 \mathrm{~mm}$, width $23 \mathrm{~mm}$; almost oval in shape, broadest at about midwing; membrane dark, the veins and cross veins light; several oval light spots framed by dark pigmentation are distributed as shown in figure I9; anterior margin slightly concave at its middle; posterior margin undulated; apex broadly rounded. Sc long, R I without terminal branches; R-Rs area only a little broadened with a dense series of oblique cross veins; $R$ with only three branches, two of them forked; MA forked three times, MP six times; anal area with about ten branches, mostly forked. Cross veins mostly regular, bordered by irregular, white stripes; anastomosis of cross veins in the anal area very rare. Hind wing: length $70 \mathrm{~mm}$, width $33 \mathrm{~mm}$; light oval spots concentrated in the distal half and

Figure 19. Lamproptilia grandeuryi Brongniart; specimen 19-8; fore wing. Holotype.

Figure 20. Lamproptilia grandeuryi Brongniart; specimen 19-8; hind wing. Holotype. 

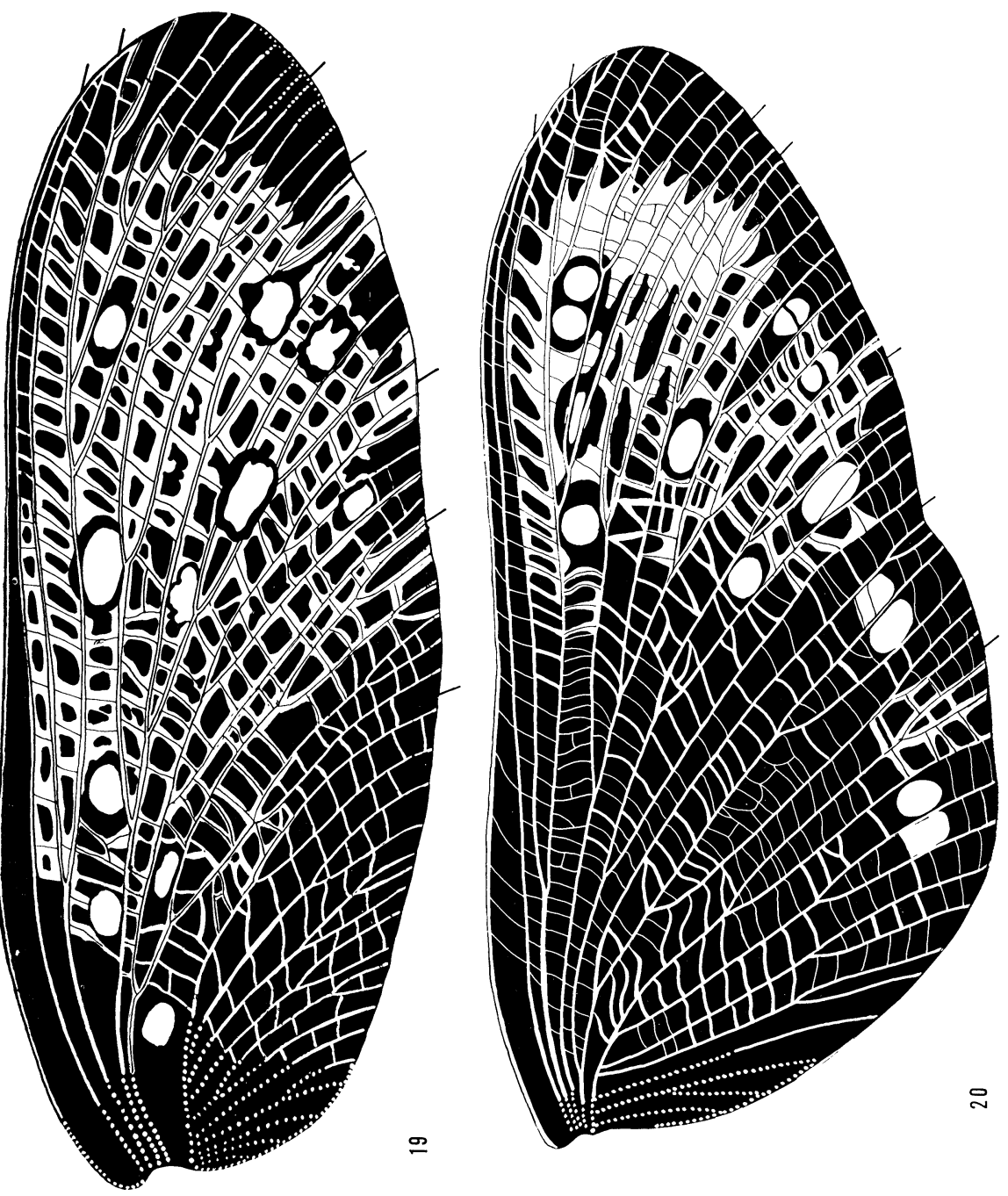
along the posterior margin; posterior margin with a pronounced convex curve beyond $\mathrm{CuP}$; anal area relatively narrow but high.

This species shows the most spectacular color pattern within the Palaeodictyoptera. The broad wings and the color pattern cause this insect to resemble superficially some of the Lepidoptera.*

\section{Spilapteridae Gen. Inc. stirrupi (Brongniart) \\ Figure 2I}

Lamproptilia stirrupi Brongniart, 1893: 347, pl. 19, fig. 9; Handlirsch, 1906: 110, pl. 12, fig. 9; Handlirsch, 1919: 21; Laurentiaux, 1953: 422.

This species was based on a small fragment of a fore wing (specimen 19-9). The venation shows few features for generic assignment. The wing fragment is $72 \mathrm{~mm}$ long and $23 \mathrm{~mm}$ wide.

\section{Family Fouqueidae Handlirsch}

Fouqueidae, Handlirsch, 1906: 98; Lameere, 1917: 103; Lameere, 1917: 30.

Type genus: Fouquea Brongniart, I893.

Handlirsch established this family for forms with richly branched venation and with a "reticulation recalling the Dictyoneuridae." $\mathrm{He}$ also associated the family with the Graphiptilidae, Spilapteridae and Lamproptiliidae. Lameere (I9I7: IO3) called attention to the relationship between Fouqueidae and Spilapteridae, and later (19I7: 30) he noted the possibility of the spilapterids being ancestral to the Dictyoneuridae (i.e., Stenodictyopteres of Brongniart). Lameere (1917: I54) considered the type genus Fouquea to be especially close to the genus Rhabdoptilus.

The family Fouqueidae is known only by fore and hind wings, in none of which are the basal portions satisfactorily preserved. The venational pattern is inseparable from that of the Spilapteridae (including the Lamproptiliidae), but is very different from that of the Graphiptilidae (including the genus Rhabdoptilus). The fouqueids can be differentiated from the spilapterids only by the presence of a dense pattern of prominent cross veins, which are mostly curved and often anastomosed and which extend over almost the entire area of the wings. This pattern of cross veins is very different from the true archedictyon of the Dictyoneuridae.

The wings are about equal in length, the hind pair broader in the basal parts. Venational pattern like that of the spilapterids, but

\footnotetext{
*Forbes (1943) actually considered Lamproptilia to be holometabolous, re-
} lated to the Neuroptera, Mecoptera, Lepidoptera, etc. 
the cross veins strong, dense, curved and often anastomosed. The fore wing with the anterior margin almost straight. Sc long, RI simple; Rs with 4-6 terminal branches; MA with at least two branches; MP branched several times; $\mathrm{CuA}$ and $\mathrm{CuP}$ with at least two branches; several anal veins. The hind wings have a venation like that of the fore wings. Both pairs of wings are usually marked by clusters of rounded spots. The body structures are entirely unknown.

As noted above, the family Fouqueidae is related to the Spilapteridae and especially resembles those genera of spilapterids which have many cross veins, such as Epitcthe, Tectoptilus, etc. There seems to be a tendency in the Fouqueidae for $\mathrm{MA}$ and $\mathrm{CuA}$ to be less branched than in the Spilapteridae and for $\mathrm{CuP}$, on the other hand, to be more branched. The cuticular thickening near the wing base, which is so distinctive in some of the Spilapteridae, is only doubtfully present in the Fouqueidae; none of the specimens which I examined has the wing base clearly preserved. However, it does seem to be visible in Professor Carpenter's photograph of the type of Fouquea needhami Lameere, one of the two fossils which I could not find in the Paris Museum.

Fouquea is the only genus of the family known from the Commentry shales; the genus Neofouquea Carpenter (1967) from the Westphalian of Illinois, also appears to belong here.

\section{Genus Fouquea Brongniart}

Fouquea Brongniart, 1893: 372 (pro Oustaletia Brongniart, 1885: 66, nec Oustaletia Trovessart, 1885: 66); Handlirsch, 1906: 98; Lameere, 1917: 154.

Archaecompsoneura Meunier, 1909: 41; Meunier, 1909: 137.

Type species: Fouquea lacroixi Brongniart, I893 (SD, Handlirsch, 1906).

The genus Fouquea was erected by Brongniart for lacroixi and sauvagei. In 1909, Meunier described Archaecompsoneura superba, which was synonymized by Lameere (1917: 154) with Fouquea; in the same paper, Lameere added two more species to Fouquea, comstocki and needhami, figures of which have never been published. In my opinion, comstocki is a synonym of lacroixi, but sauvagei (based on specimen I9-II) is herein referred to uncertain family position in the Palaeodictyoptera because of the very fragmental condition of the type specimen. The following is a diagnosis of the genus Fouquea.

Wings with relatively strong membrane. Color markings usually forming clusters of rounded spots, irregularly distributed over the 
wings. Hind wing broader in proximal half, similar in venation to the fore wing. Cuticular thickening near the wing base probably present, although not definitely observed; oblique supporting cross veins missing. RI without terminal branches; Rs with 4-6 branches, the first one forked; MA usually with a long fork; MP forked several times; MA originating very close to the first fork of MP; both $\mathrm{CuA}$ and $\mathrm{CuP}$ branched; several anal veins.

Neofouquea Carpenter differs from Fouquea in having a narrower sc-r area and in the presence of a relatively large area of reticulation along the posterior portion of the wing. The species of Fouquea occurring in the Commentry shales are lacroixi Brongniart, superba Meunier, and needhami Lameere.

\section{Fouquea lacroixi Brongniart}

Figure 22 and 24

Fouquea lacroixi Brongniart, 1893: 372, pl. 19, fig. 10; Handlirsch, 1906: 98, Lameere, 1917: 154.

Fouquea comstocki Lameere, 1917: 155 (New synonymy).

This species was based by Brongniart on a single, well preserved hind wing, lacking the basal portion (specimen 19-10). Lameere (1917: 154) was of the opinion that superba Meunier was probably a fore wing of lacroixi, but although I know the latter species only by Dr. Carpenter's photograph (the original type not being found in the Paris Museum), I am convinced that it is a hind wing and also that it is specifically distinct from lacroixi (see figure 25). The type specimen of comstocki Lameere very probably is a fore wing of lacroixi, the venational pattern being almost identical, and the smaller size noted by Lameere, being insignificant as a specific character. At the present time, only the badly preserved reverse of the type of lacroixi (specimen 19-10) is in the collections of the Museum in Paris, but I was able to study the specimen of comstocki. The nature of the cross venational pattern is the same in both of these two specimens, but it seems to be a finer pattern in the hind wing. The following account of the species is based upon the photograph of the obverse and upon my examination of the reverse of the type of lacroixi and of the type specimen of comstocki.

Wings with a slightly convex anterior margin. Apical part broad, rounded, the apex directed posteriorly. Anterior and posterior margins almost parallel. Fore wing: length $49 \mathrm{~mm}$, width $\mathrm{I} 7 \mathrm{~mm}$, equally broad except for the apical third. Subcostal area in the proximal third in the form of a band; Rs with 4-5 branches, the first forked twice; MA with a long simple fork; MP forked five 
21
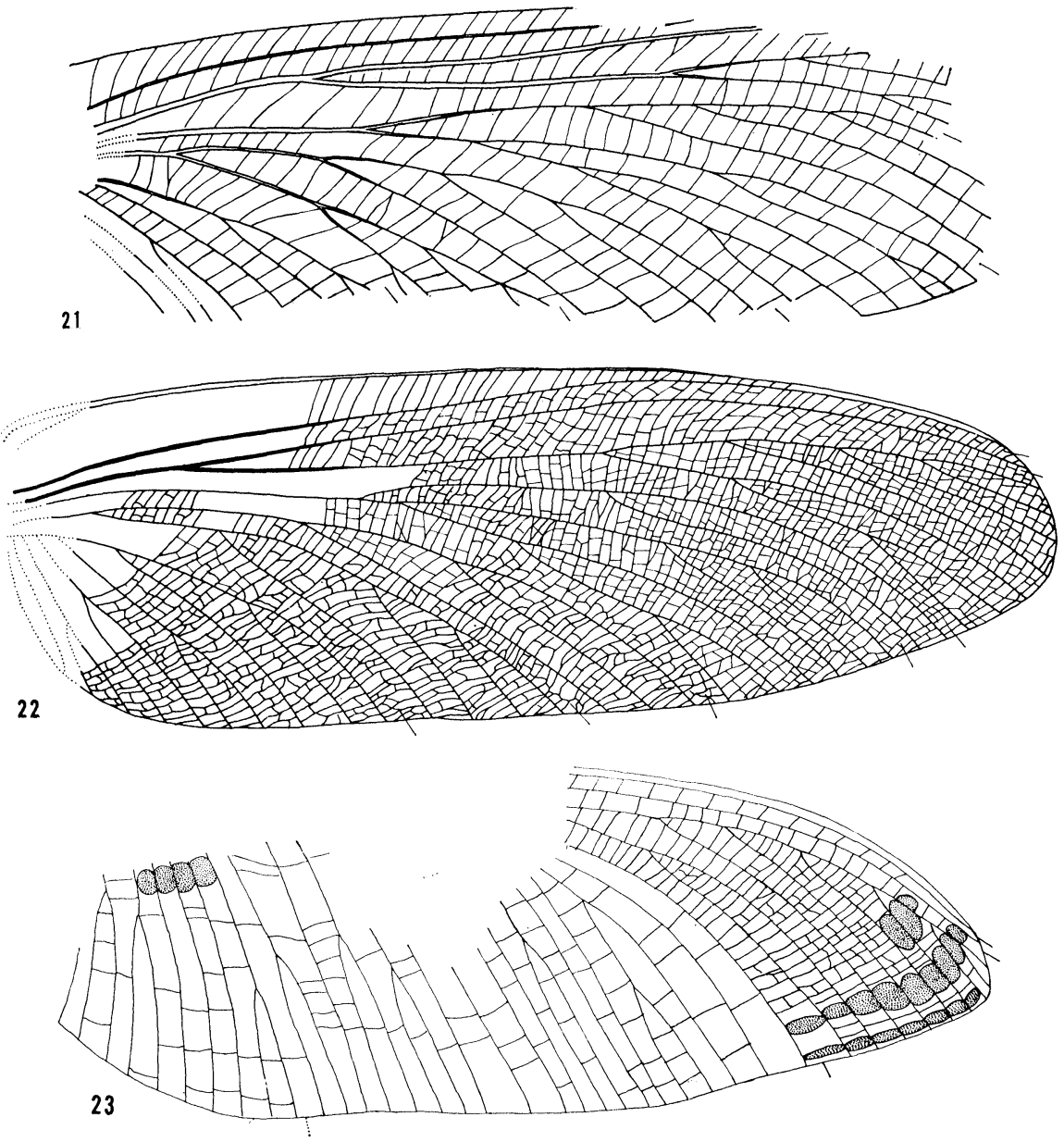

Figure 21. Spilapteridae inc. gen.; specimen 19-9; fore wing. Originally described as Lamproptilia stirrupi Brongniart, 1893.

Figure 22. Fouquea lacroixi Brongniart. Originally described as Fouquea comstocki Lameere, 1917.

Figure 23. Compsoneura formosa (Brongniart); specimen 19-2; fore wing. Holotype. 

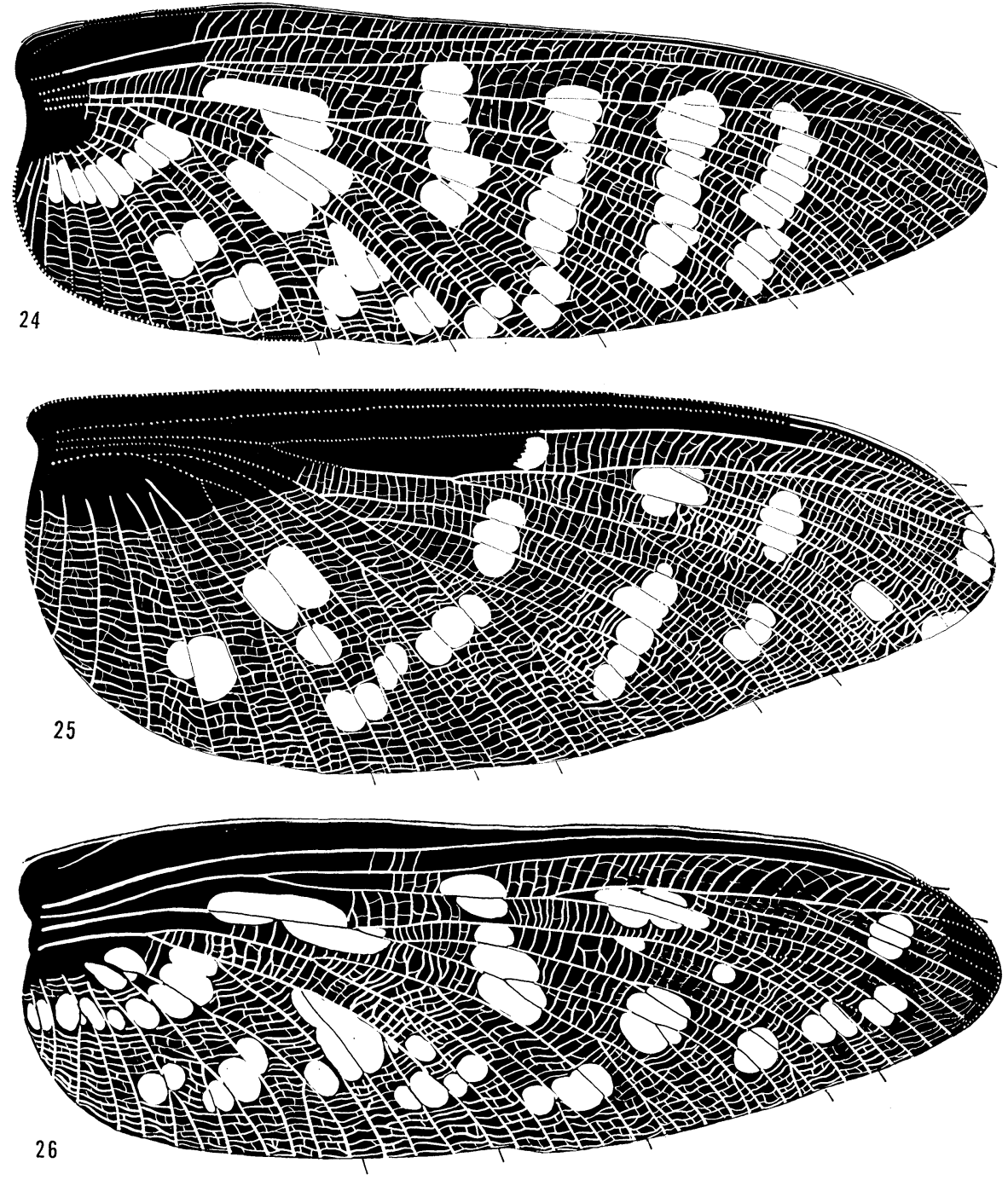

Figure 24. Fouquea lacroixi Brongniart; specimen 19-10; hing wing. Holotype.

Figure 25. Fouquea superba (Meunier); hind wing. Holotype.

Figure 26. Fouquea needhami Lameere; fore wing. Holotype. 
times; $\mathrm{Cu}$ dividing near the base; $\mathrm{CuA}$ with 2-3 long branches, $\mathrm{CuP}$ with 3-4 branches; about five anal veins, mostly forked, $\mathrm{AI}$ forked twice. Hind wing: length probably $55 \mathrm{~mm}$, width $18 \mathrm{~mm}$ (according to Brongniart). Hind wing almost uniformly broad except for the apical third; cross venation finer than in the fore wing.

The hind wing, as represented by the type specimen I9-IO, differs from the fore wing described by Lameere (as comstocki) in having an extra branch on $\mathrm{CuA}$, the second Rs branch forked, and mostly simple anal branches, the last feature being the usual one for the hind wings of spilapterids. These differences, in my opinion, are within the limits of individual variation.

\section{Fouquea superba (Meunier)}

Figure 25

Archaecompsoneura superba Meunier, 1909: 139; Meunier, 1909: 41, fig. 1; Meunier, 1909: 13, pl. 1, fig. 8; Handlirsch, 1919: 19, fig. 22.

Fouquea superba, Lameere, 1917 : 154.

This species is based upon a single specimen consisting of a hind wing, lacking the anterior margin. Unfortunately, I could not locate the type specimen in the Museum, and I have had to base my account on a photograph of the fossil made by Professor Carpenter in 1938. With the exception of the cubital veins, which are indistinct, the wing venation has been worked out satisfactorily. This fossil was erroneously considered by Lameere (I9I7) to be the fore wing of lacroixi. The color pattern, shown in figure 25 , is only approximate.

Hind wing: length $50 \mathrm{~mm}$ (according to notes by F. M. Carpenter, I938), broadest in the proximal half; posterior margin very slightly concave in the apical third; apex slightly pointed, directed posteriorly; anal area rounded; Rs with five branches, the first forked twice; MA forked twice, MP forked five times; $\mathrm{CuA}$ with one branch, $\mathrm{CuP}$ with two branches; anal area high with about six branches; iA forked twice.

The hind wing of superba differs from other species of the family in the relatively narrow cubital area, and in the small number of cubital branches; the wing itself is broader than that of lacroixi.

\section{Fouquea needhami Lameere}

Figure 26

Fouquea needhami Lameere, 1917: 155.

This species is based upon a well preserved specimen consisting of a fore wing, which has not been figured. Unfortunately, I was not 
able to find the type specimen in the Museum collection, but I have been able to use a good photograph of it made by Professor Carpenter in 1938. The venational pattern can be worked out from this photograph satisfactorily, although the color pattern given in the figure is only approximate.

Fore wing: length $55 \mathrm{~mm}$, width $19 \mathrm{~mm}$; anterior and posterior margins nearly parallel for the basal two-thirds of the wing; apical part slightly elongate and narrow; anterior margin very slightly concave, posterior margin convex at the $\mathrm{CuP}$ area; anal area moderately rounded; costal area broad at the base, abruptly narrowed distally; Rs with six branches, the first forking; MA with a long simple fork, MP with seven branches; $\mathrm{CuA}$ forked four times, $\mathrm{CuP}$ with a series of three branches; anal area with seven branches, Ar forked five times.

This species differs from all related members of the genus in having more numerous branches on $\mathrm{Rs}$ and in having $\mathrm{CuA}$ forked several times. It differs from lacroixi by the narrowed apical part of the wing.

The following genus, Compsoneura, is tentatively placed in the family Fouqueidae. As pointed out below, the absence of detailed information about the structure of the species in this genus prevents a satisfactory determination of its family affinities.

\section{Genus Compsoneura Brongniart}

Compsoneura Brongniart, 1893: 334 (pro Zeilleria Brongniart, 1885: 63; nec Zeilleria Bayle, 1878); Handlirsch, 1906: 104; Lameere, 1917: 149.

Type species: Compsoneura fusca (Brongniart) (SD, Handlirsch, 1906).

'This genus was established by Brongniart for two species, fusca and formosa, both based on hind wings. It has previously been placed in the family Spilapteridae. However, in the spilapterids, both MA and $\mathrm{CuA}$ are usually richly branched, while $\mathrm{CuP}$ tends to be simple; the cross veins are usually not very numerous, and are rarely anastomosed. In the fouqueids, on the other hand, MA and $\mathrm{CuA}$ usually have only I-2 branches; $\mathrm{CuP}$, so far as known, is always branched, and the cross veins are very dense and very often anastomosed. The venation of Compsoneura seems more like that of the hind wings of the fouqueids (e.g., Fouquea superba) than it does that of the spilapterids; also the color pattern is very suggestive of that of $\mathrm{Neo-}$ 
fouquea Carpenter, which is clearly a fouqueid. On the other hand, the cross veins, although denser than in the spilapterids, do not reach the density and strength of those of Fouquea and Neofouquea. Since I was able to find in the Museum only the type of formosa, a poorly preserved wing fragment, more detailed comparisons are not possible.

Wings apparently equal in length, the hind wing broader in the basal part. Color markings in the forn of stripes or rounded spots; RI without terminal branches; Rs with 4-7 branches, the first of them forked; MA usually with one branch, MP forked several times; $\mathrm{CuA}$ with several branches, $\mathrm{CuP}$ branched; several anal veins. Cross veins numerous, slightly curved, often anastomosed, denser in the distal half of the wing.

\section{Compsoneura fusca (Brongniart)}

Figure 27

Zeilleria fusca Brongniart, 1885: 63, pl. 5, fig. 2.

Compsoneura fusca Brongniart, 1893: 335, pl. 19, fig. 1; Handlirsch, 1906: 104, pl. 11, fig. 25; Lameere, 1917: 149; Handlirsch, 1919: 20.

This species was based by Brongniart on the single specimen, I9-I, consisting of almost complete hind wings, a remnant of the fore wing, and the abdomen with ovipositor and cerci. Unfortunately, the type specimen could not be found in the collection of the Museum. The following account is based upon Lameere's description and upon the photograph made by Professor Carpenter in 1938. Unfortunately, the body structures are not clearly shown in the photograph.

Hind wing: length $38 \mathrm{~mm}$, width $15 \mathrm{~mm}$ (according to Brongniart, 1893). Hind wings short and broad, abruptly narrowing toward the apex; anterior margin almost straight; apex pointed, directed posteriorly to a slight extent; Rs with four branches, the first forked; MA probably originating near the first fork of MP, with one short branch; MP with about nine branches; $\mathrm{CuA}$ with one branch; $\mathrm{CuP}$ forked three times; about eight anal veins, mostly forked. Cross veins dense, apparently fine, often anastomosed, less abundant in the anal area.

Length of abdomen $31 \mathrm{~mm}$ (according to Brongniart, I893), ending in two stout cerci, densely covered by hair; abdomen relatively narrow, composed of ten visible, subequal segments, the first and second being somewhat narrower than the others; ovipositor short, stout, and curved. 


\section{Compsoneura formosa (Brongniart)}

Figure 23

Zeilleria formosa Brongniart, 1885: 63.

Compsoneura formosa, Brongniart, 1893: 336, pl. 19, fig. 2; Handlirsch, 1906: 104, pl. 11, fig. 21; Lameere, 1917: 146.

This species was based by Brongniart on specimen 19-2, which consists of a very poorly preserved fragment of a hind wing. Its assignment to Compsoneura was questioned by Handlirsch ( I906), but Lameere accepted that position.

The hind wing is very weakly preserved, and apparently flattened, so that the branches of $\mathrm{M}$ and $\mathrm{Cu}$ cannot be clearly separated from each other. The cross veins are clearly preserved only in the apical third of the wing; in the rest of the wing only a few cross veins are visible. Nevertheless, Brongniart's assignment of formosa to Compsoneura is probably correct, since the insect shows similar patterns of cross veins and of color to that of fusca.

Hind wing: length $5 \mathrm{I} \mathrm{mm}$, width $19 \mathrm{~mm}$. Rs with seven branches, the first forked. About eight anal veins, some of them forked. Cross veins dense and fine, often anastomosed, less abundant in the anal area.

This species differs from fusca in its larger size, in the more extensive branching of $\mathrm{M}$ and $\mathrm{Cu}$, and in the strengthening of the costal margin by the concentration of veins there.

\section{Family Mecynostomatidae fam. nov.}

I am establishing this family on the genus Mecynostomata, represented by a single species, dohrni Brongniart. The type and only known specimen, which has the venation faintly preserved, was figured only roughly by Brongniart; it was subsequently incorrectly described by Handlirsch (1906), who confused the beak with a leg and referred the genus to an unidentified family in the Palaeodictyoptera. Lameere (I9I7) corrected some of Handlirsch's errors and noted that the genus required a separate family, although he did not propose a name for it. Lameere's description of both the body structure and the wings is very inaccurate, and his conclusions on the relationship of Mecynostomata to the Homoiopteridae is without real foundation.

Using glycerin on the wings to improve the visibility of the venation and a coating of ammonium chloride for the improvement of the impression of the body structures, I have been able to work out the structure of the head, with its beak, the front leg, and three 


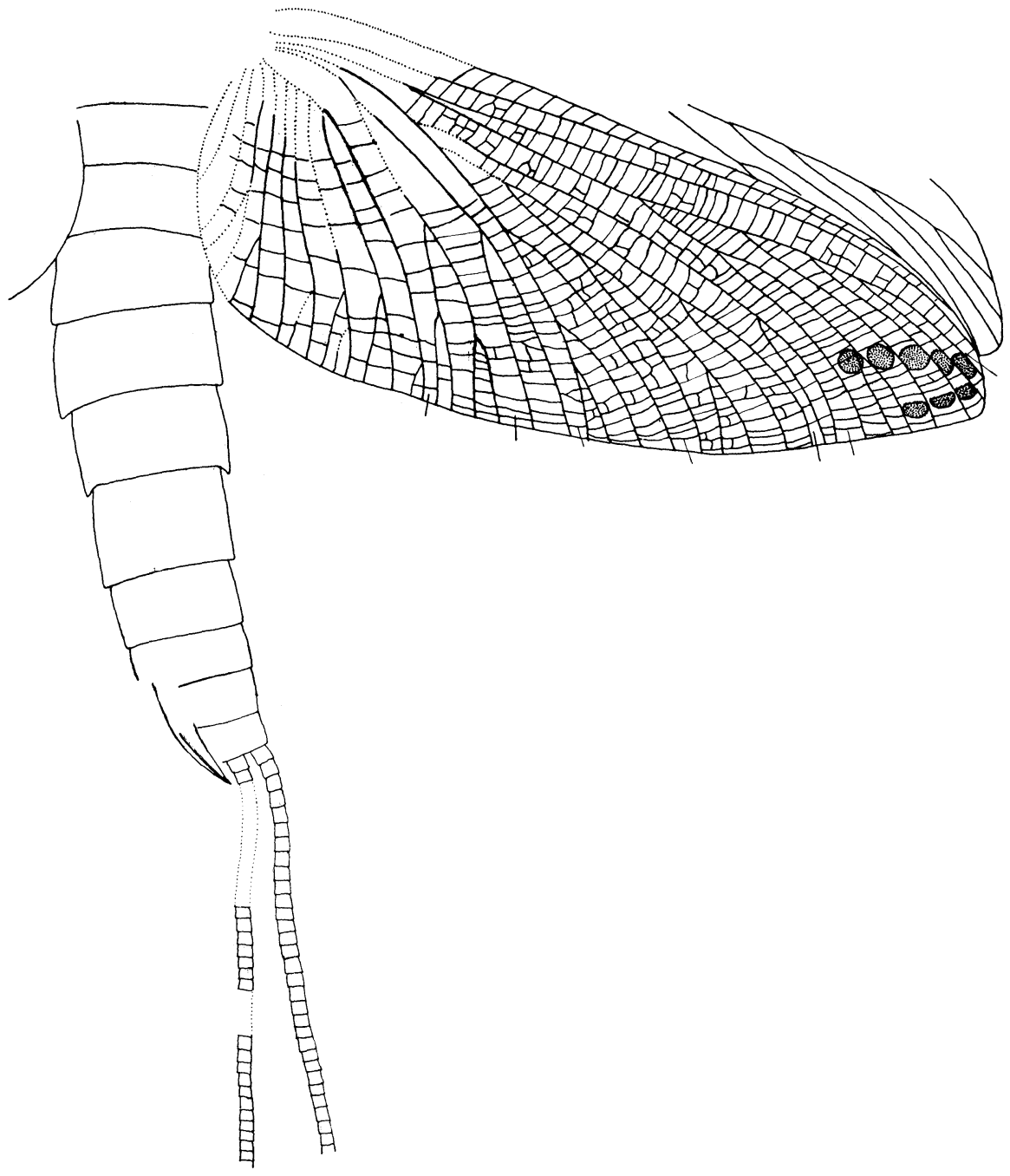

Figure 27. Compsoneura fusca (Brongniart); specimen 19-1. Holotype. 
wings. The fore wing shows a broad subcostal area, unique among the Palaeodictyoptera, and very short $\mathrm{Sc}$ and $\mathrm{Rs}$, both of which justify the establishment of a separate family. On the other hand, the branched $\mathrm{MA}$ and $\mathrm{CuA}$ and the nature of the cross venation are very suggestive of the Spilapteridae. In all probabliity, the Mecynostomatidae represent a specialized group derived from some spilapterid ancestors.

The structural feature which contributes most to our knowledge of the Palaeodictyoptera is the beak, which shows a long lanceolate labrum. In this specimen only, so far as known, the stylets can be seen separate from each other at the end of the beak. The outer pair of stylets are broad and shorter than the others, the inner pair are protruding distally with needle-like tips; at the same time, the terminal parts of the outer pair are slightly bent upwards, while the inner pair are completely straight. It is possible that this represents the beak in its position of actual feeding. Another feature contributed by the specimen of dohrni is the detailed structure of the terminal segments of the leg, showing five nearly equal tarsomeres and broadly spaced claws, with a robust arolium. The following account is different from that which has appeared in previous discussions of $M e c y$ nostomata, being based upon the observations which I have made on the specimen using the techniques already noted.

The wings were broad and short, almost equal in length and width; Sc short, terminating on $\mathrm{R}$; subcostal area very broad in the fore wing; branches of $\mathrm{Rs}$ and $M$ curving posteriorly in the fore wing; $\mathrm{MA}, \mathrm{MP}, \mathrm{CuA}$, and $\mathrm{CuP}$ branched; anal area with several veins; anal area somewhat larger in the hind wing; cross veins dense, slightly irregular, sometimes anastomosed.

Body structures: Head very small, with large, conspicuous eyes. Beak long; labrum elongate; palpi long; clypeus oval. Prothoracic lobes with radiating veins and numerous cross veins. Legs relatively long; tibiae slightly. longer than femur; tarsus five-segmented, with claws and arolium.

\section{Genus Mecynostomata Metcalf}

Mecynostomata Metcalf, 1952: 230 (pro Mecynostoma Brongniart, 1893: 451, nec Mecynostoma Graff, 1882).

Type species: Mecynostoma dohrni Brongniart (OD).

Brongniart originally listed five specimens in his description of dohrni: 37-8, 37-9, 39-10, 37-I and 37-12. Handlirsch, in 1919,

Figure 28. Mecynostomata dohrni (Brongniart); specimen 37-8. Holotype. 

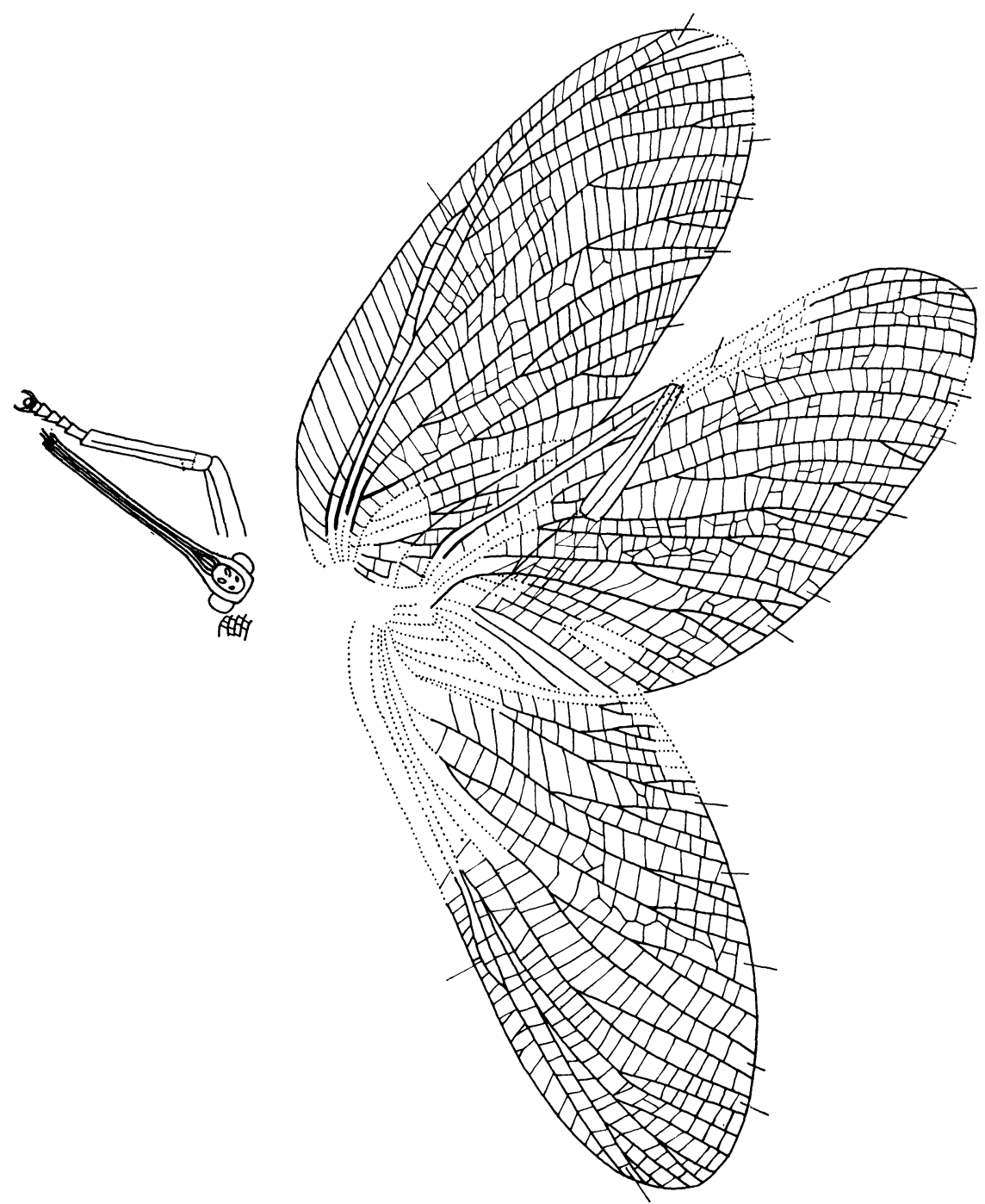
in effect designated specimen $37-8$ as the lectotype of dohrni by placing the additional specimens in other species, as follows: 37 -I I and 37-12 were placed in a distinct genus Mecynostomites brongniarti ; 37-9 to a new genus and species Paramecynostoma dohrnianum; and specimen 37-IO to another new genus and species, Pseudomecynostoma dubium. All of these four specimens consist of wing fragments, poorly preserved and are not sufficient to permit family classification. These genera are here placed in the Palaeodictyoptera incertae familiae. The following account is based upon the lectotype specimen of dohrni (37-8).

Wings dark in color. Fore wings: anterior margin convex, subcostal area very broad in the basal half; Sc, R, Rs very close to each other; $R$ and $R s$ bent in the apical part so as to be parallel with the anterior margin; first branch of Rs arising soon after its origin; MA weakly branched, MP with several branches; $\mathrm{CuA}$ forked several times, $\mathrm{CuP}$ sending off a few branches. Cross veins in the subcostal area long, bent and regular. In the hind wing the subcostal area is narrow, and Rs and $M$ are not markedly curved towards the posterior margin.

The short condition of Sc apparently developed independently in several families of the Palaeodictyoptera, such as the Breyeriidae, Calvertiellidae, etc., probably in conjunction with the development of short and broad wings with numerous cross veins. It does not apparently indicate phylogenetic relationship.

\section{Mecynostomata dohrni (Brongniart)}

Figure 28

Mecynostoma dohrni Brongniart, 1893: 452, pl. 37, fig. 8; Handlirsch, 1906: 120, pl. 13, fig. 1; Lameere, 1917: 102; Lameere, 1917: 184; Handlirsch, 1919: 24, figs. 26-27; Laurentiaux, 1953: 415.

Mecynostomata dohrni, Metcalf, 1952: 230.

The lectotype specimen, $37-8$, shows three faintly preserved wings, a very well preserved head, showing the clypeus, labrum and beak, with faint indications of palpi, and with almost a complete fore leg.

The clypeus is rather small in comparison with that of other Palaeodictyoptera. The labrum is elongate, lanceolate in form, a type which was quite common in the Palaeodictyoptera. The terminal parts of the inner stylets of the beak are very thin, pointed, and straight, while the outer pair is much broader, obtuse at the ends and probably flexible to some extent. The fore leg shows five well preserved tarsal segments, the first the longest; the claws are robust and the arolium is circular. For some reason, both Handlirsch and 
Lameere distinguished only three tarsal segments, although five are clearly visible with the coating of ammonium chloride. The wing venation is visible in great detail only under glycerin. It was incompletely figured by Brongniart, and misinterpreted by Lameere; Handlirsch even published reconstructions of the wings, these bearing little resemblance to the actual fossil structure.

Fore wing: length $50 \mathrm{~mm}$, width $21 \mathrm{~mm}$. Costa sharply curved towards the base. Fore wing almost oval in shape; apex rounded, placed at about the wing axis; subcostal area abruptly broadened shortly beyond the base; Sc terminating on $\mathrm{R}$ just beyond midwing; Rs originating shortly before midwing, close to $R_{I}$; Rs sending off five curved branches, which may be forked, the first fork originating close to the origin of Rs; MA with one, MP with 3 branches; $\mathrm{CuA}$ forming a long branching fork, $\mathrm{CuP}$ with 3 branches. Anal area with seven veins, mostly branched.

Hind wing: length $49 \mathrm{~mm}$, width $23.5 \mathrm{~mm}$, broadest just before midwing. The anterior margin straight, posterior margin moderately concave. The hind wing differs from the front wing in having markedly narrower costal area, in the less pronounced curvature of Rs, and the branches of $M$, and in having more branches on MP. Cross veins fine, dense, mostly curved, sometimes anastomosed and rather irregular.

Body structures: Head small with large conspicuous eyes. Clypeus small, oval, with two pairs of transverse ridges. Length of beak 20 $\mathrm{mm}$; labrum lanceolate, reaching about one-sixth of the complete beak length. Shape of prothoracic lobes unknown, but its membrane not much sclerotized, and having radiating veins connected by numerous cross veins. Femur of fore leg $8 \mathrm{~mm}$ long; tibia $9.5 \mathrm{~mm}$ long; tarsus $3.8 \mathrm{~mm}$ long. The tarsus is composed of five tarsomeres, the first of them being slightly longer than the others, the last one slightly shorter than the others; claws robust, widely divergent, curved. Arolium circular, as long as the last tarsal segment. Hind leg with the tibia $15 \mathrm{~mm}$ long.

Bolton, H.

\section{REFERENCES}

1917. On Some Insects from the British Coal Measures. Quart. Journ. Geol. Soc. $72: 43-62$.

\section{BraUer, F.}

1886. Ansichten über die palaeozoischen Insekten und deren Deutung. Ann. kk. Nat. Hofmus. Wien. 1: 87-125.

Brongniart, C.

1885. Les insectes fossiles des terraines primaires. Bull. Soc. Rouen. 1885 : 50-68. 
1893. Recherches pour servir à l'histoire des insectes fossiles des temps primaires. $493 \mathrm{pp}$. Atlas, $44 \mathrm{pp}$. [thesis].

Carpenter, F. M.

1938. Two Carboniferous Insects from the Vicinity of Mazon Creek, Illinois. Amer. J. Sci. 36 (5) : 445-452.

1964. Studies on North American Carboniferous Insects. 3. A Spilapterid from the Vicinity of Mazon Creek, Illinois (Palaeodictyoptera). Psyche, 71(3): 117-124.

1965. Studies on North American Carboniferous Insects. 4. The Genera Metropator, Eubleptus, Hapaloptera and Hadentomum. Psyche, $72(2)$ : 175-190.

1967. Studies on North American Carboniferous Insects. 5. Palaeodictyoptera and Megasecoptera from Illinois and Tennessee with Discussion on the Order Sypharopteroidea. Psyche, 73(1): 58-84.

Carpenter, F. M. and E. S. Richardson, JR.

1969. Megasecopterous Nymphs in Pennsylvanian Concretions from Illinois. Psyche, 75 (4): 295-309.

FORBES, W. T. M.

1943. The Origin of Wings and Venational Types in Insects. Amer. Midland Naturalist, $29(2): 381-405$.

Handlirsch, A.

1906. Die fossilen Insekten und die Phylogenie der rezenten Formen. Leipzig. $430 \mathrm{pp}$.

1911. New Palaeozoic Insects from the Vicinity of Mazon Creek, Illinois. Amer. J. Sci., 31 : 297-326; 353-377.

1919. Revision der palaeozoischen Insekten. Denkschr. Akad. Wiss. Wien. Math. Naturw. Kl., 96: 82 pp.

1921. Palaeontologie. In Schröders Handbuch der Entomologie, 3, $306 \mathrm{pp}$

1922. Fossilium catalogus I: Animalia. Insecta palaeozoica. Berlin. $230 \mathrm{pp}$.

1937-39. Neue Untersuchungen über die fossilen Insekten mit Ergänzungen und Nachträgen sowie Ausblicken auf phylogenetische, palaeogeographische und allgemeine biologische Probleme. I. Ann. naturh. Mus. Wien, 48: $140 \mathrm{pp} ; 49: 240 \mathrm{pp}$.

LAMEere, A.

1917. Revision sommaire des insectes fossiles du Stephanien de Commentry. Bull. Mus. Paris, 23: 141-200.

1917. Sur les insectes houillers de Commentry. Bull. Soc. Zool. Fr., 42: 27-37.

1917. Palaeodictyoptères et subulicornes. Bull. Soc. Ent. Fr., 1917: 101-104.

1935. Précis de zoologie. Univ. Bruxelles, 4: 174-214.

LaurentiauX, D.

1953. Classe des Insectes. In Traité de Paléontologie, Piveteau. Paris: $397-527$.

Kukalova, J.

1958. On Czechoslovakian Spilapteridae Handlirsch (Insecta-Palaeodictyoptera). Acta Univ. Carolinae, Geol., 3 : 231-240. 
1960. New Palaeodictyoptera of the Carboniferous and Permian of Czechoslovakia. Sbornik UUG, 25: 239-251.

Martynov, A. V.

1931. New Permian Palaeoptera with a Discussion of some Problems of Their Evolution. Trav. Inst. Paleozool. Acad. Sci., 1: 1-44.

1931. Palaeozoic Insects from the Kuznetsk Basin. Bull. Geol. Prosp. Serv. USSR, 49(10): 73-100.

MetCAlF, $Z$. P.

1952. New Names in the Homoptera. J. Wash. Acad. Sci., 42: 226-231. Meunier, F.

1909. Nouveaux insectes de Stephanien de Commentry. Bull. Mus. Hist. Nat. Paris, 15: 37-40.

1909. Insectes de Stephanien de Commentry. Bull. Mus. Hist. Nat. Paris, 15 : 40-49.

1909. Nouvelles recherches sur les insectes du terrain houiller de Commentry. Ann. Paleont. 4: 125-152.

1909. Nouveaux Paleodictyoptères et Protorthoptères du Stephanien de Commentry. Ann. Soc. Sci., 33: 139-140.

Richardson, E. S. JR.

1956. Pennsylvanian Invertebrates of the Mazon Creek Area, Illinois. Fieldiana: Geology, $12(2):$ 15-56.

Rohdendorf, B. B., And E. E. Becker-Migdisova, O. M. Martynova,

A. G. SHAROV

1961. Paleozoic Insects of the Kuznetsk Basin. Trudy Paleont. Inst. 85: $705 \mathrm{pp}$.

ROHDENDORF, B. B., ET AL.

1962. Principles of Paleontology. Akad. Nauk SSSR, Moscow: 535 pp. Tillyard, R. J.

1924. Kansas Permian Insects. Part I. The Geologic Occurrence and the Environment of the Insects. C. O. Dunbar, with Description of a New Palaeodictyopterid. R. J. Tillyard. Amer. Journ. Sci., 7: 1-209.

1925. Kansas Permian Insects. Part 4. The Order Palaeodictyoptera. ZALESSKY, G. Amer. Journ. Sci., 9: 328-335.

1946. Sur un nouveau representant de l'ordre des palaeodictyoptères du Paleozoique superieur de bassin de Kousnetsk. Moscow. Ob. Isp. Prirody, Biol. (N.S.), 51: 58-62. 

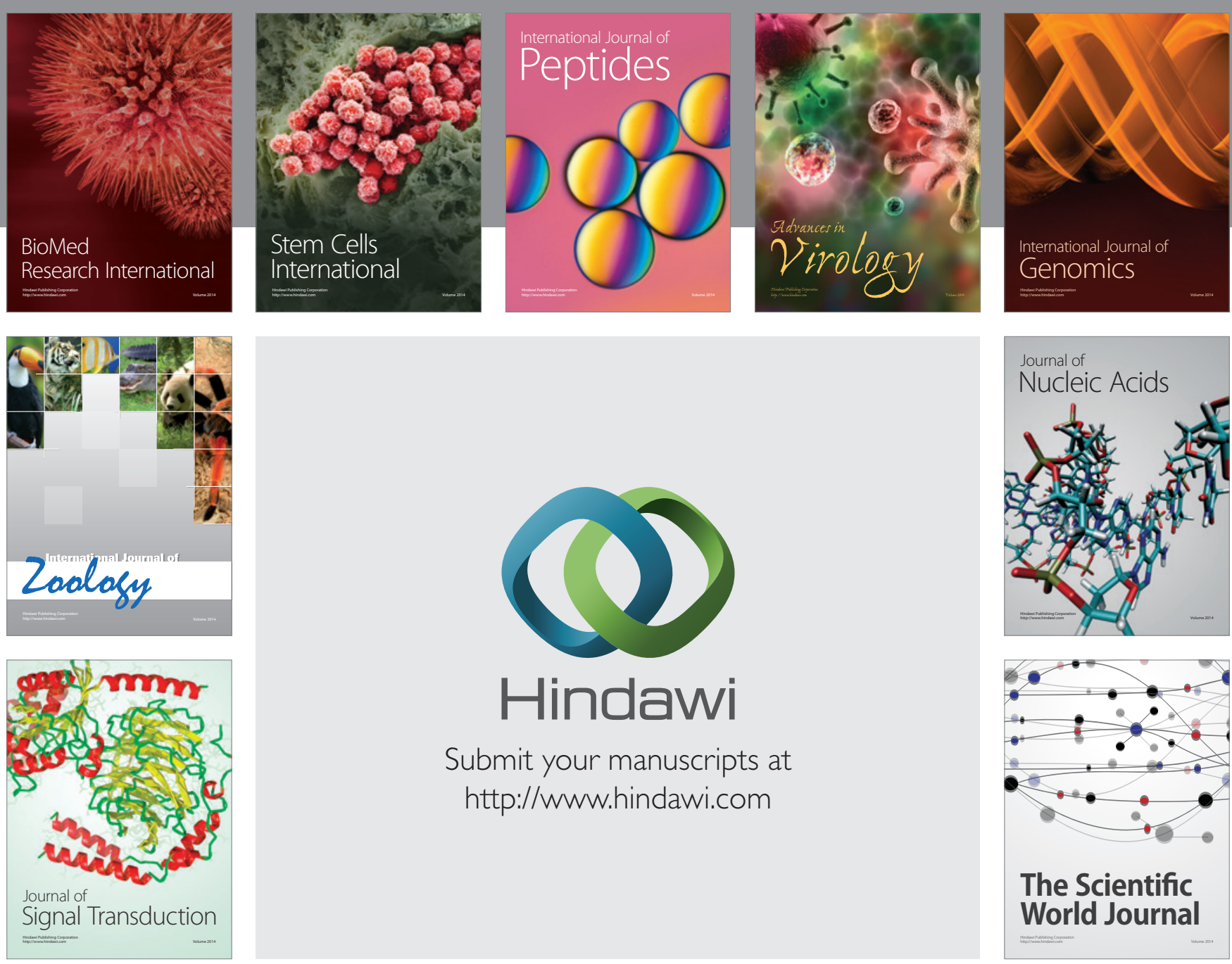

Submit your manuscripts at

http://www.hindawi.com
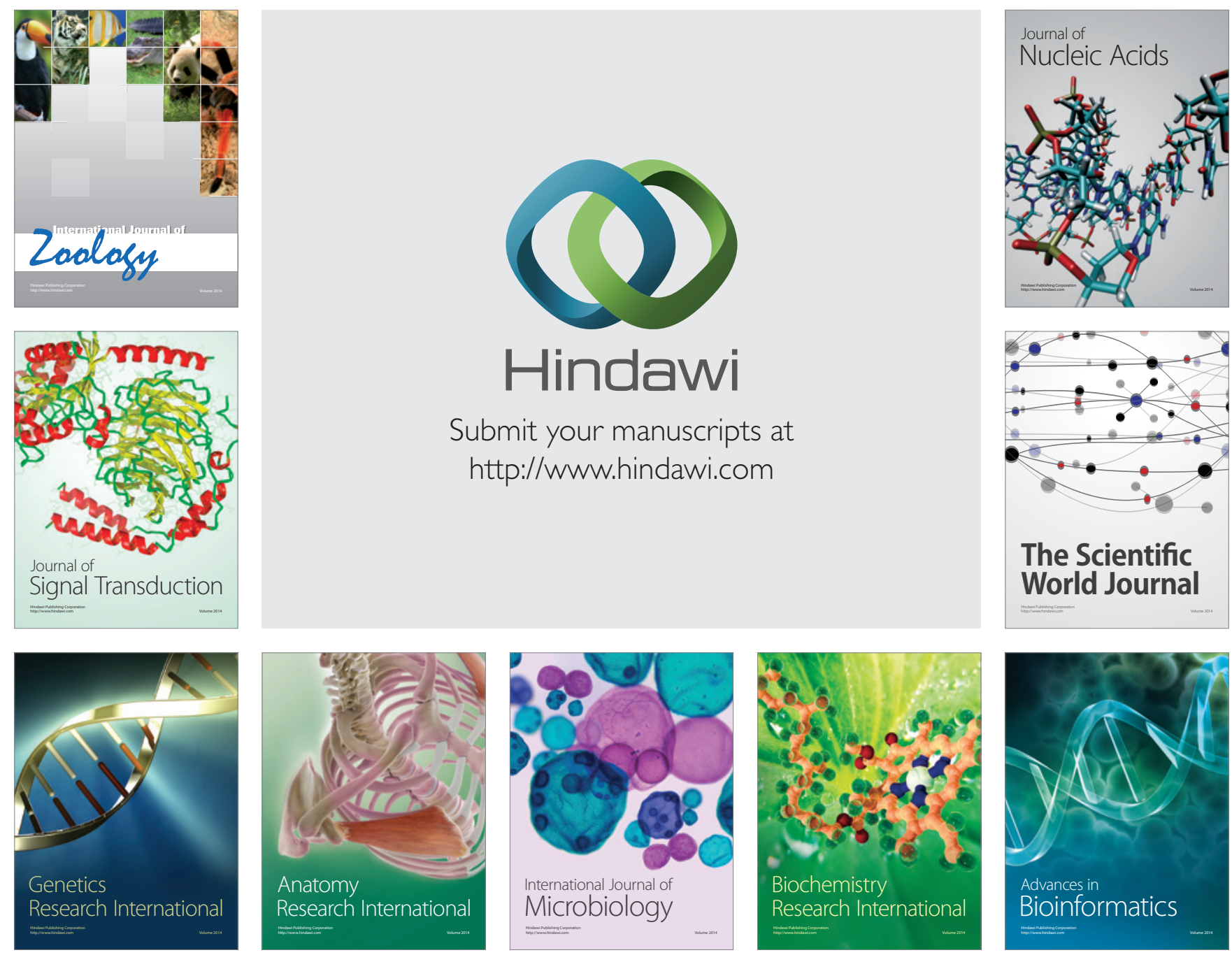

The Scientific World Journal
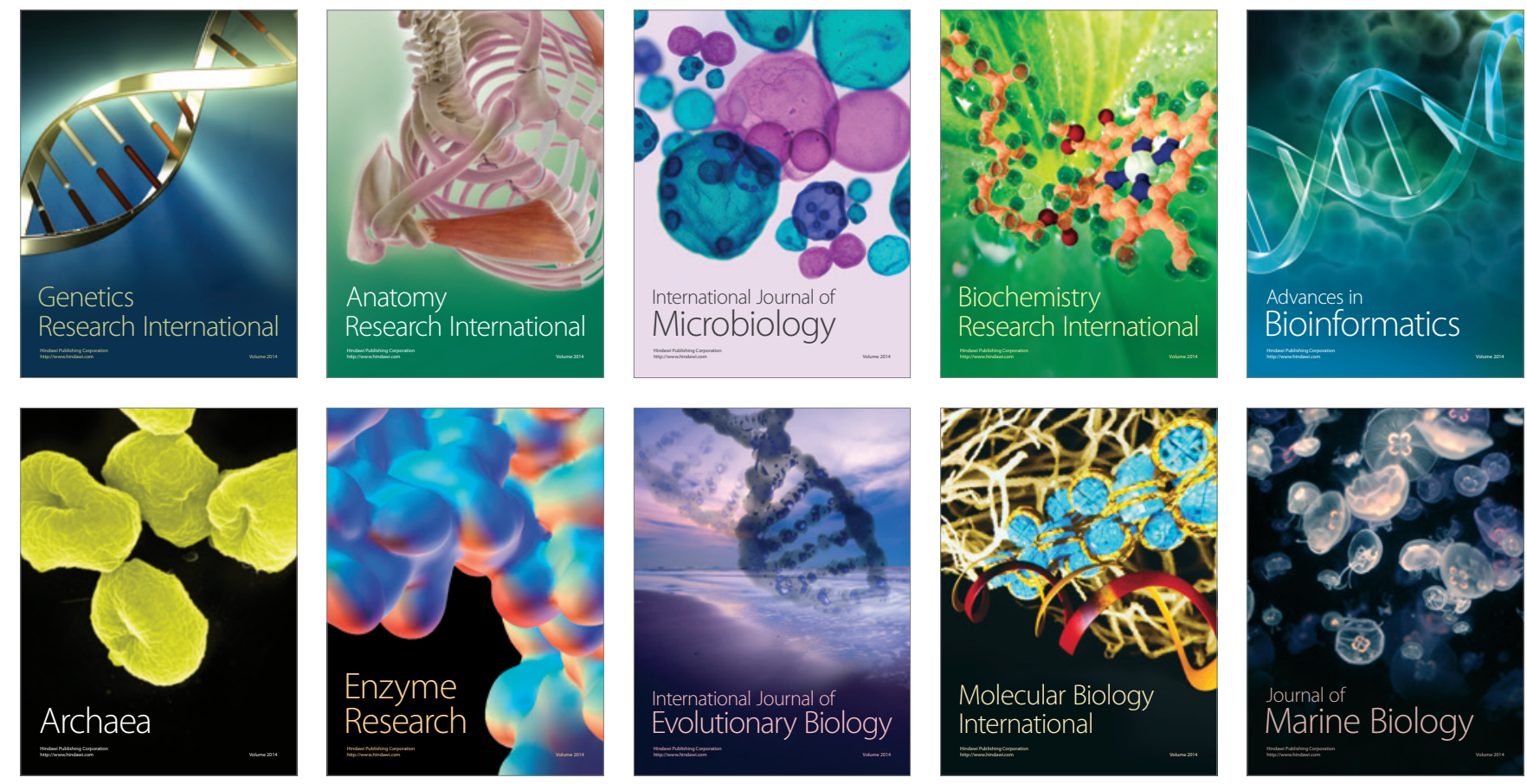